\title{
Patara'dan Bir Grup Oinophoros: İkonografi ve Üretim Üzerine Gözlemler
}

\author{
[A GROUP OF OINOPHOROS FROM PATARA: OBSERVATIONS ON \\ ICONOGRAPHY AND PRODUCTION]
}

Feyzullah ŞAHIN

\author{
Anahtar Kelimeler \\ Oinophoros, Patara, Seramik, Roma Imparatorluk Dönemi.
}

\section{Keywords}

Oinophoros, Patara, Pottery, Roman Imperial Period.

\section{ÖZET}

Roma Imparatorluk Dönemi kalıp yapımı kabartmalı seramik gruplarından biri olan oinophoroslar, çeşitli varyasyonlara sahip pelikeler, amphoralar, tek kulplu testiler, lagynoslar, mitolojik karakterlerin veya grotesk figürlerin model alındiğ l kaplar ve tondosunda kabın zeminine aplike edilmiş kabartmalı bir madalyon bulunan sı̆̆ kâse formunda phiale ya da pateraları içerir. Genellikle iki ya da üç kalıp kullanılarak üretilmiş bu seramiklerin süsleme repertuarında, Dionysos kültüyle bağlantılı anlatımların ağırlıklı olarak tercih edildiği, bununla birlikte çeşitli mitosların, günlük yaşamdan erotik anlatıların ve gladyatör dövüşü gibi sahnelerin de bu çeşitlilik içinde yer bulduğu görülmektedir. Oinophoros grubu seramiklerin, ilk olarak Augustus Dönemi'nde Knidos atölyelerinde üretilmeye başlandiğı tespit edilmiştir. Bu üretimi, MS 1. yüzyılın ortalarında Pergamon ve MS 2. yüzyılın ikinci yarısında İasos atölyelerinin takip ettiği görülmektedir.

Patara'da ele geçen oinophoros grubu seramikler içinde bir amphora ve sekiz patera ile madalyon üretiminde kullanılmış olabilecek bir kalıp, çalışmanın ana konusunu oluşturmaktadır. Üretim ve süsleme tekniği açısından oinophoros kabartmalı kalıp yapımı seramikleri içinde yer alan Patara örneklerinde de başta Dionysos kültüyle bağlantıl olmak üzere çeşitli mitolojik anlatımların yer bulduğu görülmektedir. Yapığımız araştırmalar ve benzer örnekler, Patara oinophoros grubu seramiklerinin, stilistik olarak Knidos ve İskenderiye örnekleriyle yakın ilişki içinde olduğunu göstermektedir. Bu durum bize özellikle oinophoros grubundaki pateraların, Akdeniz'deki dağılımı ve ticari ağlarla ilgili bilgi sağlarken, tercih edilen ikonografilerdeki ortak yönler ise kökleri Hellenistik Dönem'e uzanan ortak inançlar/düșüncelerin Roma Imparatorluk Dönemi’ndeki devamlılı̆̆ını göstermesi açısından önemli veriler sunmaktadır. Üzerinde olasılıkla Dionysos tasvirinin bulunduğu kalıp ise bir patera madalyonunu biçimlendirmek için son derece uygun yapısıyla Patara'da oinophoros tipi patera üretimi olabileceğine dair izler taşımakta ve Anadolu'daki oinophoros üretim merkezlerine, başta Patara olmak üzere yeni atölyelerin eklenme olasılığının arttı̆̆ını göstermektedir.

\footnotetext{
ABSTRACT

Oinophoroi, which is one of the molded relief ware in Roman Imperial Period, includes various types of pelikai, amphoras, single-handled jugs, lagynoi, pots modeled according to mythological characters or grotesque figures, and shallow phialai or paterae with an relief medallion applied on their tondo. In the decoration repertoire of these ceramics, which are usually produced using two or three molds, it is seen that expressions related to the Dionysus cult are predominantly preferred, however, various myths, erotic narratives from daily life and scenes such as gladiator fights are also included in this diversity. It was determined that the Oinophoros group ceramics were first produced in Cnidian workshops in the Augustus Period. It is seen that the Pergamene workshops in the mid-1st century AD and Iasian workshops in the second half of the 2 nd century AD followed this production.
} 


\begin{abstract}
Among the oinophoros group ceramics found in Patara, an amphora and eight paterae constitutes the main subject of the study. In addition to these finds, a mold that may have been used in the production of medallions of the paterae is examined. In terms of production and decoration technique, it is seen that various mythological scenes, especially in connection with the Dionysus cult, are found in the Pataran samples, which are among the oinophoros molded relief ware. Our research and other similar examples show that oinophoros group ceramics in Patara are stylistically similar to examples from Cnidus and Alexandria. While this situation provides us the information on the commercial networks and the distribution of oinophoros group paterae in the Mediterranean, the common characteristics of the preferred iconographies present important data by showing the continuity of the common beliefs and thoughts, which dates back to the Hellenistic Period, in the Roman Imperial Period. With its structure highly suitable to shape a patera medallion, the mold that presumably has a representation of Dionysus bears traces of oinophoros type patera production in Patara, and it shows that it is likely to add new workshops to the oinophoros production centers in Anatolia, and notably in Patara.
\end{abstract}

\section{Giriş}

Roma İmparatorluk Dönemi'nde, iki veya daha fazla kalıp kullanılarak üretilmiş, kabartma süslemeye sahip bir dizi seramik, "oinophoros grubu" olarak adlandırılmaktadır. Bu isimlendirme, John Hoppkins Üniversitesi koleksiyonundaki, çift kulplu ve silindirik gövdeye sahip kendine özgü biçimi olan kabartmalı bir amphoranın dip kısmına kazıma olarak yazılmış "OINOФOROC" yazıtından gelmektedir. ${ }^{1}$ Knidos'taki kazı çalışmalarında elde edilen buluntu ve bulgulara dayanılarak, bu seramik grubu kentin atölyelerine tahsis edilmiş ve bu nedenle ilk üretim yerlerine ithafen "Knidos - Kalıp Yapımı - Kabartmalı Kapları" olarak da adlandırılmışlardır. ${ }^{2}$ John Hopkins Üniversitesi koleksiyonundaki amphoranın incelenmesi sonucunda tespit edilen -aşağıda ayrıntılı olarak değineceğimizüretim tekniği kullanılarak üretilmiş ve aynı zamanda kabartmalarda işlenen konular ile özgün stilleri açısından birbirleriyle ilişkili olduğu saptanan farklı formlar da bu seramik grubu içinde değerlendirilmiştir.

Patara'da ele geçen gerek korunma durumlar1 gerekse kabartma yüzeyindeki deformasyon seviyeleri açısından farklılık gösteren bir amphora, sekiz patera ve pateraların madalyon bölümünün üretiminde kullanılmış olabilecek bir kalıp, çalışmanın ana konusunu oluşturmaktadır. Patara oinophoros grubunu oluşturan seramikler ve kalıp kentin farklı alanlarında sürdürülen kazılarda; Meclis - Kuzey Sur (Kat. No. 3, 5, 9), Tepecik Nekropolü (Kat. No. 2, 8, 10) Liman Caddesi Bat1 Portikosu (Kat. No. 6), Nero Hamamı (Kat. No. 1), Sekizgen Çeşme (Kat. No. 7) ve Su Yolu sondajları (Kat. No. 4) çalışmalarında

1 Robinson 1909: 30-38, Res. 3.

2 Bailey 1972/1973; Mandel 1988: 99-191; Hayes 1997: 72-74; Hayes 2008: 105-107; Pastutmaz 2009: 29. ele geçmiştir. Kapların büyük çoğunluğu, söz konusu alanlarda farklı dönemlere ait buluntuları içeren karışık katmanlardan ve dolgu/akıntı toprak içinden ele geçtiğinden tarihlendirmelerinde katmanlardan elde edilen verilerden ziyade, karş1laştırma ve stil kritik yöntemine başvurulmuştur. Bununla birlikte, buluntu konumları, varsa kontekst veriler ve ait oldukları tabakaların özellikleri, buluntuların tekil olarak ele alındığ 1 alt bölümlerde metin içinde sunulmuştur.

Aşağıda öncelikle, oinophoros grubu seramikler üzerine yapılan araştırmalarda üretim tekniğ $i$ bağlamında paralellik gösterdiği tespit edilen form repertuarına ve bunların taşıdı 11 tasvirlerde işlenen konu yelpazesine değinilecektir. Ardından üretim teknikleri incelenerek, farklı seramik formlarının oinophoros grubu içinde tanımlanmasında öne çıkan noktalar üzerinde durulacaktır. Sonrasında ise Patara'da ele geçen oinophoros grubu seramikler ve kalıp hem üretim teknikleri hem de kabartmalarda yer alan ikonografileri açısından değerlendirilecektir.

\section{Form ve Süsleme}

Oinophoros seramik grubu, 1950'lerden itibaren bir dizi araştırmaya konu olmuş ve bu çalışmalarda hem form hem de kabartmalarda işlenen konular açısından çeşitliliklerin görüldüğü tespit edilmiştir. ${ }^{3}$ Gruba ismini de veren silindirik gövdeli "pelike benzeri" amphoralar, tek kulplu testiler, lagynoslar ve tondosunda kabartma madalyon bulunan silindirik formlu, uzun tek kulplu pateralar en sık görülen formlar arasındadır. Satyros ve maenad gibi mitolojik öğelerin ya da grotesk figürlerin model alındığı örneklerin

3 Robinson 1909; Hausmann 1954/1955; Bailey 1972/1973; Heimberg 1976; Bailey 1979; Salomonson 1979; Salomonson 1980; Mandel 1988; Baldoni 2003; Pastutmaz 2009. 
yanı sıra insan, hayvan (koç, panter vb.) ya da phallos formundaki kabartmalı seramikler de bu grup içinde yer alan başlıca formlar olarak belirlenmiştir. ${ }^{4}$

Oinophoros seramik grubunun süsleme repertuarı birçok temayı kapsamaktadır. Genellikle mitolojik anlatımların olduğu bu süslemelerde, özellikle Dionysiak figürlerin ve pastoral anlatımların ağırlıklı olarak tercih edildiği görülmektedir. Dionysos kültüyle ilintili sahnelerde, Tanr1 Dionysos'un yanı sira maenadlar, satyroslar, silenoslar vd. ya tek olarak ya da bir sahne içinde çeşitli anlatımlarda karşımıza çıkmaktadır. Bununla birlikte, süslemelerde yer bulan tanrı ve tanrıçaların, konu olarak seçilen mitosların ve bunların uygulamalarının büyük bir varyasyona sahip olduğu da söylenebilir. Zeus-Ganymedes ya da Zeus-Leda mitosunun çeșitli betimlemeleri, Herakles'in ișlerini konu alan sahneler ya da Aphrodite ile ilgili mitoslar bunlar arasındadır. Günlük yaşamdan da sahneler yer bulmuştur. Erotik sahneler çeşitlilik gösterir. Üzüm bağları arasında tasvir edilen bireysel figürler, savaşçılar ve çeşitli gladyatör dövüşü sahneleri de süsleme kompoziyonları içinde yer bulmuştur. ${ }^{5}$

\section{Üretim Teknikleri}

Oinophoros grubu içinde yer alan seramiklerin belirlenmesi için en önemli kriterlerden biri üretim tekniği olmuştur. ${ }^{6}$ İki ya da daha fazla sayıda

4 U. Mandel'in form tiplerine göre düzenlenmiş kapsamlı bir katalog sunan çalışması için bk. Mandel 1988. Knidos ve Pergamon'da ele geçen oinophoros grubu formların birlikte yer aldığ ${ }_{1}$ çizimler için bk. Baldoni 2003: 6-11, Res. III-IV.

5 Mandel 1988: 43-89, 133-176; Pastutmaz 2009: 71-123.

6 Oinophoros grubu üzerine yapılan ilk çalışmalarda ele alınan seramik tiplerinin bir kısmının, örneğin süslemede kullanılan figüratif bezemelerin düzenlenmesindeki uyuşmazlıklar gibi tutarsızlıklar, bu tekniğin bakış açısını anlamak için yetersiz olduğunu ortaya koymuştur. Memphis ve Kahire gibi merkezlerde bulunan güçlü Misır süslemelerine sahip kabartma kaplar da aynı teknikle yapılmıştır. Dolayısıyla kabartmalarda işlenen konular, kabartmaların stili ve form repertuarı da kapların tanımlanmasında önem kazanmaktadır. Bu nedenlerle, MÖ 3-1. yüzyıl Mısır örnekleri teknik açısından "öncü” olarak görülmemektedir; bk. Mandel 1988: 3-4. Bu gruptaki seramiklerin üretim tekniği “Knidos kandilleri”nin üretiminde kullanılan yöntemle tamamen benzerdir. Bu gözlem, D. M. Bailey (1972/1973: 12) tarafından kalıp kullanılarak yapılan bu seramikler, temel olarak benzer prensipler üzerine imal edilmiş olsalar da kapalı ve açık seramiklerin üretiminde farklı uygulamalar söz konusudur.

Amphoralar, pelikeler, testiler, lagynoslar gibi kapalı seramikler üzerine yapılan gözlemler, bunların genellikle iki kalıp kullanılarak üretildiklerini göstermektedir. İki parça halinde hazırlanmış kalıplara kilin bastırılmasıyla, kabı oluşturacak iki yarım parçanın hem seramik formunu hem de kabartma süslemelerin şeklini alması sağlanmıştır. Ardından, kalıplar içlerindeki nemli kil birbirine birleşecek şekilde kapatılmıştır. Kurumaya bırakıldıktan sonra, nem oranı azalıp küçük bir oranda küçülen seramiğin alınması için kalıplar açılır. Bu hafif kurumuş ancak hala nemli olan seramiğin son düzenlemeleri genelde çark üzerinde gerçekleştirilmiştir. Kulplar ve bazı durumlarda kaideler ayrı ayrı modellenmiş ve daha sonra seramik üzerine yerleştirilmiştir. Kabın iki yarım parçasının birleştiği yerlerde ve kulpların sırt kısmında birleşim izleri birçok kapta takip edilebilmektedir. Ahşap bir spatula ile bezemenin rötuşlarının yapılmasının ardından seramiklerin renklendirilmesi muhtemelen tek bir seferde astara daldırma yöntemiyle gerçekleştirilmiştir. ${ }^{7}$

Açık kap formları içinde sıklıkla üretilenlerin başında phialeler, ${ }^{8}$ skyphoslar ${ }^{9}$ ve pateralar ${ }^{10}$ gelmektedir. ${ }^{11}$ Patera, ${ }^{12}$ genel olarak sığ ve geniş

British Museum'daki malzemenin analizi temelinde açıklanmıştır; ayrıca bk. Baldoni 2003: 1.

7 Hausmann 1954/1955: 125-126; Mandel 1988: 3-5; Baldoni 2003: 1-2; Pastutmaz 2009: 43-44.

8 Mandel 1988: 112, Lev. 31, Kat. No. K 125; Doksanalt1 2006: 433, 434, K141 Çiz. 371-375.

9 Mandel 1988: 113, Lev. 32, Kat. No. K 195, K 196; Doksanalt1 2006: 434, 435, K142 Çiz. 376-379.

10 Salomonson 1979: 119, Res. 1-7; Doksanalt1 2006: 432, 433, K140 Çiz. 363-365; Pastutmaz 2009: 45-59.

11 Açık seramiklerin, kulp bölümleri olmaksızın, sadece madalyon ya da gövde kısımları günümüze ulaşmış ise birbirlerinden ayırt edilmeleri oldukça zordur. Kapların bir sap/kulpa sahip olup olmadığ1 da çoğu zaman netlik kazanmamaktadır. Skyphoslar dış yüzlerinin de kabartmaya sahip olmasıyla daha kolay tanımlanabilirler. Genel olarak bakıldığında ise tüm olarak geçmeyen açık kaplar için ortak bir terim olarak "patera" isimlendirmesinin daha yaygın olarak kullanıldığı anlaşılmaktadır; bk. Pastutmaz 2009; Rekowska 2013; Buora vd. 2016. Bu nedenle bu çalışmada da benzer kullanım sürdürülmüştür.

12 Merkezinde bir omphalos bulunan, saplı (Hilgers, 1969: Res. 59-61) veya sapsiz kaselerin (Matthews 
bir kâse formunda gövde ile gövdeye yatay olarak birleștirilmiş silindirik kulplardan oluşan bir kap formudur. Oinophoros grubu içinde yer alan pateraların tondolarında, kabartma süslemeye sahip bir "madalyon" bulunmaktadır. Kabın ana bölümünü de oluşturan kâse formundaki gövde, silindirik uzun kulp ve kâsenin tondosuna yerleştirilen kabartmalı madalyon bölümleri ayrı ayrı kalıplarda üretilerek birleştirilmiş̧lerdir. Kabın dış yüzü, kaideden başlayarak ağza doğru uzanan birbirine oldukça yakın yivler ya da ağza doğru genişleyen dil motifleriyle süslenmiş olabildiği gibi tamamen yalın bırakılan örnekler de mevcuttur. ${ }^{13}$ Halka kaidenin iç kısmında, bronzdan yapılmış prototiplere ${ }^{14}$ öykünmenin açık bir şekilde görüldüğü, keskin profilli iç içe geçmiş eş merkezli bantlar ya da pişmiş toprak örneklere özgü olarak ortaya çıkan tekli-ikili rozetler bulunabilmektedir. Pateraların tasarımındaki diğer bir karakteristik unsur, madalyon üzerinde kabartmaların uygun bölümlerine düzenli ya da düzensiz bir şekilde açılmış küçük deliklerdir. $\mathrm{Bu}$ delikler, madalyonun, kâsenin tondosuna yerleştirilmesi sırasında oluşan iki katmanlı yapı arasında kalan hava kabarcıklarının, pişirim sirasinda herhangi bir deformasyona neden olmaması ve isının iki katman arasına rahatlıkla nüfuz edebilmesi amacıyla yapılmıştır. ${ }^{15}$ Türün

1969: 33-38) ya da casseruole tipinde kapların da (Eggers 1955: 196-244) bu isimle anıldığı görülebilmektedir; bk. Sahin 2018: 22-23.

13 Salomonson 1979: 118; Pastutmaz 2009: 46.

14 Tondosunda kabartmalı madalyon bulunan metal kâseler Hellenistik Dönem "toreutik" sanatında önemli bir yer tutmuştur. Roma Cumhuriyet Dönemi'nde de gelişmiş bir metal endüstrisine sahip Capua'da, MÖ 1. yüzyılın ikinci yarısında üretimi artarak süren kaliteli günlük kullanıma yönelik bronz kaplar, imparatorluğun tüm eyaletlerine ihraç edilmeye başlanmıştır. Bu kaplar arasında en popüler formlardan biri de pateralardir (Lamb 1929: 242 244). Pişmiş toprak pateraların, günlük kullanıma yönelik üretilen bronz pateraların etkisinde geliştiği ve ilk örneklerin tamamen bu metal kapların birer taklidi olarak üretildikleri anlaşılmaktadır. Dolayısiyla, oinophoros grubundaki pateralar Roma İmparatorluk Dönemi'ndeki tondosu kabartma süslemeli bronz pateraların pişmiş topraktan imitasyonlarıdır (Mandel 1988: 99; Hayes 1997: 73; Baldoni 2003: 14; Pastutmaz 2009: 34). Tondosunda kabartmalı madalyon bulunan Roma imparatorluk Dönemi bronz patera örnekleri için bk. Treister 2020: 565-610, Res. 10-14.

15 Salomonson 1979: 117-119, Res. 1; Pastutmaz 2009: 45-47. s1kl1kla görülen teknik bir özelliği olarak bu küçük delikler birçok paterada tespit edilmiş olsa da havalandırma deliklerinin kullanılmadığı örnekler de bulunmaktadır. ${ }^{16}$

Oinophoros kabartmalı seramik grubunu tanımlamada üretim tekniğinin yanı sıra, düzensiz kalınlıkta cidarlar, dikkatsiz şekillendirme sonucunda kabın dış yüzünde görülebilen belirgin birleşim hatları ve çoğu durumda kolaylıkla çözülebilen az dayanıklı ince astar, diğer teknik kriterler arasında yer almaktadır. Bu teknik özellikler, ürünün kalitesinden çok niceliğe önem veren bir işçilikle üretilmiş seri üretim kaplar olduğunu göstermektedir. ${ }^{17}$ İçki ve sofra kullanımının yanı sıra bazı formların kült kabı olarak kullanıldığı anlaşılmaktadır. ${ }^{18}$

\section{Patara Oinophoros Grubu}

\section{Amphora - Kat. No. 1 (Fig. 1)}

Patara'da ele geçen bir amphorada, oinophoros grubundaki kapalı kapların üretim tekniği ve kabartmalardaki stil özellikleri tanımlanabilmektedir. Amphoranın gövdesinin bir bölümü, kaidesi ve kulplarından biri eksiktir. Dışa çekik ağızlı, kısa ve geniş bir boyuna sahip amphoranın diagonal omuz bölümünden gövdeye geçişi iki yivle keskinleştirilmiş profillidir. Gövde yarı yükseklikten itibaren kaideye doğru sürekli daralmaktadır. Dairesel kesite sahip kulpun ön ve arka yüzlerinde çentikler/yivler bulunurken sırt kısmı düzleştirilmiştir. Kulpun düzleştirilmiş sirt bölümü ve buna paralel olarak gövde de de devam eden düşey ince birleştirme hattı, yukarıda da bahsettiğimiz ikili kalıptan üretim tekniğinin izlerini taşımaktadır. Amphoranın özellikle gövde bölümünde görülen düzensiz cidar kalınlıkları da grubun bir diğer ortak üretim özelliğini göstermektedir.

Kat. No. 1, Patara'nın Nero Hamamı çalışmalarında, MS 1. yüzyıldan MS 4/5. yüzyıla kadar farklı tarihlere ait buluntuların ele geçtiği karışık bir tabakadan ele geçmiştir. Bu nedenle stratigrafik veri, amphoranın tarihlendirilmesinde oldukça geniş bir tarih aralığı sunmaktadır. Kat. No. 1, oinophoros grubu içinde yaygın olarak görülen silindirik gövde formuna sahip örneklerden

16 Salomonson 1979: 119, Res. 1, 4; Pastutmaz 2009: 47, Res. 7.

17 Mandel 1988, 4; Baldoni 2003, 1-2.

18 Doksanaltı 2006: 431. 
farklı özellikler göstermekte ve daha çok boyunlu amphora formuyla benzerlik içinde olduğu görülmektedir. Oinophoros grubu içinde yaygın olarak görülmeyen bu formun benzer bir örneği New York Metropolitan Müzesi koleksiyonundadır ve MS 3. yüzyıla tarihlendirilmektedir. ${ }^{19}$ Samos'tan kırık bir gövde parçası da bu formla ilişkilendirilmektedir. ${ }^{20}$

Amphoranın ağız ve boyun bölümleri yalın bırakılmıştır. Omuzda her biri uca doğru sivrilen formda yapraklardan oluşan bir kuşak yer alır. $\mathrm{Bu}$ dizideki yaprakların çerçeveleri, ana damarlar1 ve ikincil damarları yivlerle belirginleştirilmiştir. Gövde üzerinde, her iki yanında iri taneli üzüm salkımları taşıyan sarmaşıklarla sınırlandırılmış alanda, oturan bir erkek figürü ile onun bacaklarının üzerinde tuttuğu kâseden beslenen/su içen büyük bir kartal figürü yer almaktadır. Kaya üzerine oturan, profilden betimlenmiş erkek figürünün üstü çıplaktır, altında ise kısa bir tunik vardır. Başını önündeki kartala doğru eğmiş, sağ eliyle dizinin üstünde duran kabı tutarken, sol elini kartalın başının/kanadının üzerine doğru yönlendirmiştir. Figürün yüzünün genel hatları belirgin olmakla birlikte, detayları yüzeydeki aşınma nedeniyle okunamamaktadır. Erkek figürünün dizleri üzerindeki kaptan beslenen kartal neredeyse erkek figürü ile aynı boyutlara sahiptir. Kanatları yarı açık pozisyondaki kartal, bir pençesi ile figürün dizinin üstünde duran kabı kendine doğru çekerken tasvir edilmiştir. Boyun, gövde ve kanat tüyleri belirgindir.

$\mathrm{Bu}$ sahnede, Zeus ve Ganymedes mitosuna bir atfin söz konusu olduğu ve Zeus'un bir kartal olarak tasvir edildiği görülmektedir. Ganymedes'in Zeus tarafından kaçırılmasını konu edinen mitosun farklı versiyonlarında, Ganymedes'in bizzat Zeus tarafından kaçırıldığı, Zeus'un görevlendirdiği kartal tarafından kaçırıldığı ya da Zeus'un kartal kılığına bürünerek bu eylemi gerçekleştirdiği gibi çeşitli anlatılar söz konusudur. ${ }^{21}$ Mitosun, Zeus'u simgeleyen kartal ile Ganymedes'i merkeze alan tasvirlerinde ise kartalın Ganymedes'e yaklaşması, ayakta duran Ganymedes ve yanında kartal, kartal tarafından kaçırılan Ganymedes, kartalın üzerinde

19 Robinson 1909: 35-36, Res. 5-6; Hausmann 1954/1955: 136, Lev. 46, 2.

20 Hausmann 1954/1955: 136, Lev. 46, 1.

21 Erhat 1996: 116. oturan Ganymedes ve Patara örneğinde olduğu gibi kartalı besleyen Ganymedes gibi çeşitli ikonografiler görülebilmektedir. ${ }^{22}$ Kartalı besleyen Ganymedes ikonografisinin benzer örnekleri, ilk olarak MÖ 1. yüzyılda kullanılmaya başlanmış 23 ve Roma İmparatorluk Dönemi'nde de duvar resimlerinde, gemmeler üzerinde, bronz aynaların arka yüzlerinde ve pek çok farklı seramik dekorasyonunda çeşitli varyasyonlarla yer bulmuştur. ${ }^{24}$

Patara'da ele geçen amphora üzerindeki ikonografinin hem seramik grubu hem de stil açısından benzer bir örneği Knidos'ta ele geçmiştir. ${ }^{25}$ Ganymedes ve kartalın bulunduğu küçük bir bölümün kırık olarak ele geçtiği Knidos örneği, bu küçük parçanın formu hakkında çok fazla bilgi vermemesi nedeniyle bir patera olarak değerlendirilmekle birlikte kapalı bir kaba ait olabileceği de belirtilmiștir. Patara örneğindeki figürlerin ayrıntıları, Knidos örneğine göre daha çok tahrip olmuştur. Bununla birlikte Ganymedes'in saçlarının işlenişinde, kartalın tüylerinin formunda da kendini gösteren pek çok farklılık görülebilmektedir. Ancak yine de hem oinophoros grubuna ait olması hem de kabartmanın stili bu iki parçanın yakın bir bağ içinde olduğunu göstermektedir. Knidos örneği MS 2. yüzyılın ortalarına tarihlendirilmektedir. ${ }^{26}$

\section{Pateralar (Kat. No. 2-9)}

Oinophoros grubu açık kapların nerdeyse tümü üretim teknikleri ve madalyonlarda işlenen konular açısından benzerlik göstermekle birlikte, J. W. Salomonson kaidenin iç bölümünün işlenişinde kullanılan öğeler açısından iki temel grup belirlemiştir. Bunlardan ilkinde kaidenin merkezinde, iç içe geçmiş dairelerle çevrelenmiş ikili rozetler bulunmaktadır. İkinci grupta ise kaidenin iç kısmı sadece iç içe geçmiş eş merkezli çemberler şeklindeki çıkıntılardan oluşmaktadır. ${ }^{27}$

22 Sichtermann 1988: 159-166, Lev. 82-95.

23 Sichtermann 1988: 161, Lev. 86, 138.

24 Ganymedes sembolizminin Roma kaynakları, mit ve ikonografi açısından bir yorumu için bk. Greet 2015: 84-86.

25 Pastutmaz 2009: 83-88, Res. 16.

26 Pastutmaz 2009: 87.

27 Salomonson 1979: 118-119; Pastutmaz 2009: 50-51. $\mathrm{Bu}$ iki grubun yanı sıra tekli rozetlerin bulunduğu örnekler de bilinmektedir; bk. Rekowska 2013: 61-69, Res. $1 b$. 
İstatistiksel veri, ilk grup özelliklerine sahip pateraların daha fazla üretildiğini göstermektedir. İkinci grup içinde değerlendirilen pateraların kaidelerinin iç kısımlarının işleniş özellikleri, seramik kaplara has bir bezemeden ziyade, yukarıda da bahsettiğimiz metal pateraların tornada çekilerek şekillendirilen kaide özelliklerini taşımaktadır. ${ }^{28}$

Roma İmparatorluk Dönemi'nde oldukça popüler olan oinophoros grubu içindeki pateralar üzerine yapılan çalışmalarda, üretimin MS 1 . yüzyılın üçüncü çeyreğinde ${ }^{29}$ ya da genel olarak MS 1. yüzyılın ilk yarısında başladığı ileri sürülmüştür. ${ }^{30}$ U. Mandel, İtalya'da üretilen bronz prototiplerden modellenen bu kapların stilistik açıdan Augustus Dönemi'nde üretilmeye başlanmış olması gerektiğini belirtmektedir. ${ }^{31}$ Bununla birlikte Knidos'ta Kap Krio'da ve Dionysos Stoası'nda yapılan çalı̧̧malarda, Augustus Dönemi'ne tarihlendirilen kontekst içinde bulunan pateralar bu savı destekler niteliktedir. 32 Özellikle kaidenin merkezinde, bantlarla çevrelenmiş ikili rozet bulunan pateraların MS 3. yüzyılın ilk çeyreğine kadar üretildiği düşünülmektedir. ${ }^{33}$ Knidos Kap Krio'da ele geçen balık formlu patera kulpları ise MS 4. yüzyıldaki son üretimleri temsil ediyor olmalıdır. ${ }^{34} \mathrm{Bu}$ süreçte bu kap formunun, Anadolu'nun özellikle batı ve güney kıyıları başta olmak üzere, Khios ve Samos gibi Ege adalarına, Misır'da İskenderiye ve Kahire gibi merkezlere, Korfu, Brindisi ve Aquileia gibi Adriatik yerleşimlerine ve Karadeniz çevresindeki birçok merkeze yayıldığ 1

28 Salomonson 1979: 118-119. J. W. Salomonson, tondolarında, tropaion tasvirleri, zırh, kılıç, kalkan gibi motiflerin ve gladyatör isimlerinin yer aldığ 1 bir pişmiş toprak patera/kâse serisinin bronzdan yapılmış prototiplere daha yakın özellikler gösterdiğini belirtmekte ve bunları üçüncü bir grup olarak değerlendirmektedir. $\mathrm{Bu}$ pateraların, oinophoros grubu pateralarından temel fark1; kabartmaların ayrı birer madalyon şeklinde yapılmamış olmasıdır. Bu kaplar, oinophoros grubu pateralarin (madalyonlu pateaların/kâselerin) öncülü kabul edilmektedir; bk. Salomonson 1979: 119-120, Res. 8-12.

29 Salomonson 1979: 121; Mandel 1988: 127-128.

30 Baldoni 2003: 68.

31 Mandel 2000: 64-66; Doksanalt1 2006: 425.

32 Doksanaltı 2006: 425-426, 432-433. Dionysos Stoas1 için bk. Doksanaltı 2000: 80, Res. 3, 15.

33 Salomonson 1979: 120; Baldoni 2003, 68-69; Pastutmaz 2009, 51.

34 Doksanaltı 2006: 433. görülmektedir. ${ }^{35}$

Patara'da toplamda sekiz adet patera parçası ele geçmiştir. Bunların tamamı farkı kondisyonlarda korunmuş olmakla birlikte, madalyon bölümü, kaide ve gövde parçasından oluşmaktadır. J. W Salomonson, kaidesinde bronz prototiplere benzer şekilde birkaç sıra halka bulunan örneklerin kronolojik olarak daha erken bir döneme ait olabileceğini, kaidelerinin iç bölümünde tekli ya da ikili rozet bulunan örneklerin ise formun seramik örneklere tam adaptasyonuyla yaygınlaştığını ileri sürmektedir. ${ }^{36}$ Aşağıda ele alınacak örneklerin sıra düzenlemesi de öncelikle bu kriter göz önüne alınarak yapılmıştır.

\section{Kat. No. 2 (Fig. 2)}

Madalyonun, kaidenin ve gövdenin küçük bir bölümü korunmuş Kat. No. 2'nin, kaidesinin iç kısmında, kademeli olarak alçalan eş merkezli iki halka yer almaktadır. Kabın diş yüzünde, geniş aralıklı yivler radyal bir şekilde kaideden yükselir. Kırık madalyon bölümünde iki figür bulunmaktadır. Üst gövdesi ve baş kısmı korunmuş sağdaki figür, arkası dönük bir şekilde işlenmiş ve sola doğru çevirdiği başı profilden verilmiştir. Sırt çizgisi ince bir yivle vurgulanmıştır. Göz ve burun detayları kısmen korunmuş figürün saçları, alından başın arkasına doğru paralel yivler şeklinde uzanır ve başın arakasında bir topuz oluşturur. Göğüs hizasından, gövdesinin alt kısmı eksik olan ikinci figür kollarını iki yandan yukarı doğru kaldırarak başının üstünde birleştirmiş pozisyondadır. Kolları arasında kalan baş kısmında, yüzün hiçbir ayrıntısı işlenmemiş bunun yerine yan yana ve üst üste gelen düzensiz siralar halinde daire motifleriyle bezenmiştir. Eller ve parmaklar da özensiz yapılmış ve birkaç çizgi ile belirlenmiştir. İkinci figürün üst kısmında dairesel bir forma sahip olduğu anlaşılan çelenk benzeri bir motif yer alır.

Kat. No. 2'nin madalyon bölümünde korunmuş bu küçük bölümden sahneyi net olarak tanımlamamız zordur. Bununla birlikte, sahnede yer alan ve vücudunun arkası dönük, başı ise profilden betimlenmiş kadın figürünün hem duruş pozisyonu hem de saçlarının

\footnotetext{
35 Baldoni 2003: 68.

36 Salomonson 1979: 121.
} 
işlenişi açısından benzerleri, oinophoros grubu kapların çeşitli formları üzerinde yer alan kabartmalardan bilinmektedir. Pergamon'dan bir olpe ${ }^{37}$ ile bir matara ${ }^{38}$ üzerindeki sahneler bunlara örnek teşkil etmektedir. Kadın figüründen daha kısa olarak işlenmiş ikinci figürün duruşu dans eder bir şekilde olduğunu düşündürmektedir. Yüz hatları yerine olasılıkla kalıplama sonrası baskı tekniğiyle yapılmış dairesel süslemeler, panter postlarının ayrıntılarının belirtilmesinde kullanılan dairesel bezemelerin özensiz yapıdaki çeşitlemelerine benzemektedir. ${ }^{39} \mathrm{Bu}$ bağlamda, dans eden figürün başında görülen bu düzensiz izler, bir panter postuna işaret ediyor olabilir. ${ }^{40}$ Grotesk dansçı figürleri, Knidos atölyelerine atfedilen birçok kandil üzerinde yer bulmuştur. ${ }^{41}$ Ayrıca, yine Knidos'ta ele geçmiş bir patera madalyonu üzerinde benzer duruşa sahip bir pigme ${ }^{42}$ ve bir Lagynos üzerinde dans eden bir figür ${ }^{43}$ de bu dansçılar serisi içinde değerlendirilebilir. $\mathrm{Bu}$ bağlamda figürü, Anadolu'daki kabartmalı seramik repertuarına Geç Hellenistik Dönem'de giren ${ }^{44}$ ve oinophorosların üretildiği süreçte de kullanılan ${ }^{45}$ grotesk bir dansçı olarak tanımlamamız mümkün görünmektedir. Genel görünüm, bu iki figürün Dionysiak bir sahne içinde yer bulduklarını göstermektedir. Tepecik Nekropolü çalışmalarında herhangi bir buluntu katmanından bağımsız ele geçen patera, hem kaide özellikleri göz önüne alınarak MS 1-2. yüzyıl içinde değerlendirilmektedir.

37 Mandel 1988: 8, Lev. 15, P 99; Lev. IV, 6.

38 Mandel 1988: 9, 19, Lev. 15, P 128; Lev. IV, 9.

39 Knidos'tan üzerinde benzer ayrıntılara sahip panter bulunan kabartmalı patera madalyonları için bk. Salomonson 1979: 118, Res. 2; Pastutmaz 2009: 72-74, Res. 13 a, 13 c. İasos'tan panter formlu bir askos ile bir açık kap üzerindeki örnek için bk. Baldoni 2003: 66, 79, Lev. 53, 276; 56, 319.

40 Dionysos alayını konu alan tasvirlerden ve antik yaz1lı kaynaklardan Dionysos'un, töreni yöneten kült liderinin ya da alayda yer alan diğer figürlerin panter postu giydikleri bilinir; Fathy 2019: 15-17; Fuchs 1959: 108-118, Lev. 23 b, 24 b; Litvinskij vd. 1974: 99, Res. 3.

41 Bailey 1988: 62, Kat. No. Q 2842-Q 2843, Q 2884, Q 2941, Q2949, Q. 2967, Q2984, Q2986.

42 Pastutmaz 2009: 114, 115, Res. 51.

43 Mandel 1988: 172, Lev. 28, K 30.

44 Courby 1913: 422, Res. 4, 715.

45 Mandel 1988: 171-172.
Kat. No. 3 (Fig. 3)

Madalyon, kaide ve gövdenin bir kısmı korunmuş olan Kat. No. 3'ün kaidesinin iç bölümünde, iç içe geçmiş, keskin sırtlı halkalar yer almaktadır. Hem kaidenin hem de içinde yer alan halkaların oldukça sı̆g olmasının nedeni yüzyıllar içindeki aşınma olabileceği gibi, bu durum kalıbın çok fazla kullanımından kaynaklı da olabilir. Gövdede, kaideden başlayarak radyal bir şekilde uzanan yivler bulunmaktadır. Çevresi dış bükey bir halka ile sınırlandırılmış madalyonun korunmuş kısmında bir hayvan figürü bulunur. Ön bacakları gergin, arka bacakları iç dizden hafif kırılmış ve kuyruğu U şeklinde yukarı doğru kavisli bir pozisyonda duran dişi bir kurt/köpek(?), dalgalı bir zemin üzerinde profilden işlenmiştir. Hemen altta asma dalı benzeri bir motif bulunmaktadir.

Madalyonun küçük bir bölümünün korunmasından dolayı sahnenin bütünündeki anlatımin tahmin edilmesi zordur. Bununla birlikte, gerek kırık bölümden görülen çift cidarlı üretim, gerekse kabın kaide özellikleri ve dış yüzündeki radyal yivler oinophoros grubu içinde yer alan patera örneklerinden olduğunu açık bir şekilde göstermektedir. Pateralarda, madalyonun çevresi Kat. No. 3'te olduğu gibi tekli ${ }^{46}$, ikili ${ }^{47}$ veya üçlü bantlarla ${ }^{48}$ ya da kabaralardan oluşan bir bantla ${ }^{49}$ çevrelenebilmektedir. Kaide içinde kalan alanda iç içe halkaların kullanılması patera üretiminin erken özelliklerinden biri olarak kabul edilmektedir ${ }^{50}$. Ancak, birbirini takip eden gelişim-üretim aşamalarının tespitinin detaylı olarak gerçekleştirilememesi ${ }^{51}$ ve pateranın Meclis Kuzey Sur çalışmalarında dolgu toprak içinden ele geçmesi nedeniyle, genel olarak MS 1-2. yüzyıl üretimi olarak değerlendirilmektedir.

46 Breccia 1909: Res. 52. 59. 63; Salomonson 1979: Res. 2. 13a; Pastutmaz 2009: Res. 13. 13a. 38.

47 Pastutmaz 2009: Res. 7. 21. 61.

48 Pastutmaz 2009: Res. 17.

49 Breccia 1909: Res. 56. 61; Salomonson 1979: Res. 1a. 3. 4.7 a; Pastutmaz 2009: Res. 32. 46. 56a; Rekowska 2013: 61-69, Res. 1a. 4a; Buora vd. 2016: 415, Res. 2.

50 Salomonson 1979: 121. Benzer kaideye sahip pateralar için bk. Salomonson 1979: 7b; Hayes 2008, 106107, Kat. No. 1626; Pastutmaz 2009: Res. 4a-b

51 Pastutmaz 2009, 51. 52. 


\section{Kat. No. $4^{52}$ (Fig. 4)}

Madalyon bölümü ve kaidesi tüm, kabın formunun izlerini taşıyan gövde bölümü kırıktır. Kâse bölümünün dış ve iç yüzeylerinde/duvarlarında herhangi bir süsleme öğesi bulunmamaktadır. Alçak halka kaidenin iç bölümünde, üç adet eş merkezli daireyle çevrelenmiş ikili rozet motifi yer almaktadır. Kâsenin tondosunda yer alan kabartmalı madalyonun çevresi, kabaralardan oluşan iki eş merkezli daire ile çevrelenmiştir. Kabartmalı madalyonun farklı yerlerinde, yapım tekniğinin de izlerini taşıyan altı adet küçük delik yer almaktadır. Merkezde yer alan sahnede, bir erkek figür ile bir boğanın mücadelesi tasvir edilmiştir. Sakallı, olgun yaşta ve omuzlarının üstündeki bir pelerin haricinde çılak olarak tasvir edilmiş figür, başı geriye doğru dönük boğanın bir eliyle sağ boynuzunu, diğer eliyle ise çenesini yakalamıştır. Boğanın arka gövdesi erkek figürün arkasında kalmış ve arka ayakları kompozisyona uygun olarak erkek figürün arkasında gösterilmiştir. Boğanın ön ayakları sahnede anlatılan mücadeleyi destekler şekilde yukarı yükselmiştir. Bu sahne, bizlere yabancı değildir ve çokça bilinen bir mitosu, Herakles'in Girit Boğası'yla mücadelesini anlatmaktadır. Herakles'in en çok bilenen atribütlerinden biri olan lobutun, kahramanın bacakları arasında betimlenmesi de bu çıkarımı desteklemektedir.

Herakles'in Peloponnesos dişındaki ilk görevinin anlatıldığ ilk kez MÖ 6. yüzyılın son çeyreğine tarihlendirilen birçok vazoda karşımıza çıkmaktadır. Ancak, bu konunun Erken Doğu Roma İmparatorluğu Dönemi'ne kadar çeşitli varyasyonlarla tasvir sanatında kullanıldığı görülmektedir. ${ }^{53}$ Patara örneğinde olduğu gibi, Herakles'in bir eliyle boğanın boynuzundan diğer eliyle ise ağzından yakaladığ 1 andaki mücadelenin tasvir edildiği sahneler, en erken MÖ 1. yüzyıldan bilinmekle birlikte, ${ }^{54}$ kabartmalı lahitlerde, sikkelerde,

52 Kat. No. 4 kodlu patera ilk olarak, II. Uluslararas1 Sosyal Bilimlerde Kritik Tartışmalar Kongresi / II. International Congress on Critacal Debates in Social Sciences başlıklı kongrede sunulmuş ve tam metin bildiri kitabında yer almıştır. Ancak, bu kongrenin bildiriler kitabında gerçekleșen bir dizgi hatası nedeniyle eserin fotoğrafı ve çizimi yer almamıştır; bk. Şahin 2019.

53 Todisco 1990: 60-66.

$54 \mathrm{Bu}$ ikonografi, olasılıkla Lysippos'un Alyzia için yaptığı heykel grubu ile ilişkilidir ve anlatım bu pişmiş toprak veya farklı metallerden yapılmış kaplarda ya da tekstil ürünleri üzerinde, MS 6/7. yüzyıla kadar yer bulmuştur. 55

Kat. No. 4'ün ele geçtiği katman, oldukça geniş bir zamansal aralığ 1 önermekte ve bu katmandaki buluntular MÖ 1. yüzyıl - MS 3. yüzyılın sonları arasına tarihlendirilmektedir. Stilistik özellikler açısından baktığımızda ise Herakles'in güçlü yüz yapısı, küçük kabaraların birleştirilmesiyle oluşturulmuş saç ve sakalın iç içe geçmişliği gibi özellikleri ve vücudun tıknaz yapısı, MS 3. yüzyıl özelliklerini taşıdığını göstermektedir. Knidos'tan, küçük bir bölümü korunmuş bir patera madalyonu üzerinde sadece baş kısmı korunmuş Herakles'in Patara örneğiyle yakın benzerlik içinde olduğu görülmektedir. ${ }^{56}$ İskenderiye Müzesi envanterinde bulunan ve 20 . yüzyılın başlarında yayımlanan bir grup seramik içindeki bir pateranın (Env. No. Alexandria.17001) ise hem madalyonda yer alan kabartmasının hem de kaide içindeki ikili rozetin, birebir Patara örneğiyle eşleştiği görülmektedir ${ }^{57}$ (Fig. 11). MS erken 3. yüzyıl içinde değerlendirebileceğimiz Patara ve İskenderiye örnekleri, olasılıkla aynı kalıplar kullanılarak üretilmiştir. ${ }^{58}$ Aralarındaki tek fark,

eserlerin etkisinde gelişmiştir. Bu ikonografinin sunulduğu MÖ 1. yüzyıla tarihlendirilen bir yüzük taş1, tasvirin en erken tarihli örneğidir. Velletri'den bir lahit, Uffizi Lahdi ve British Museum'da bulunan bir lahit üzerindeki benzer karşılaştırma örnekleri MS 2. yüzyılın son çeyreğine tarihlendirilmektedir. Benzer sahneler, Aleksandria, Hadrianapolis, Nikopolis gibi kentlere ait sikkeler üzerinde MS 1-3. yüzyıllarda sıklıkla kullanılmıştır. MS 2-3. yüzyıla ait seramik örneklerde de sıklıkla karşımıza çıkmaktadır. MS 6. yüzyıla tarihlendirilen Koptik tekstil ürünü üzerinde yer alan betimleme ve MS 7. yüzyıla tarihlendirilen bir bronz kap üzerindeki benzer tasvirler ise bu ikonografinin son örneklerini oluşturmaktadır; bk. Todisco 1990: 67.

55 Todisco 1990: 64-65, 67.

56 Pastutmaz 2009: 104, Res. 38.

57 Breccia 1909: 364, Res. 61.

58 İskenderiye örneği MS 3. yüzyılın ilk çeyreğine tarihlendirilmektedir; bk. Todisco 1990: 64-65. Oinophoros grubu pateralarının, aynı kalıptan üretilmiş ve Akdeniz'in farklı coğrafyalarında bulunmuş örnekleri bilinmektedir. Örneğin, madalyon bölümünde bir aslanın dağ keçisine saldırması tasvir edilen Knidos'ta bulunmuş bir patera ile Utrecht Arkeoloji Enstitüsü koleksiyonunda bulunan örnek, aynı kalıp kullanılarak üretilmiştir. Khios'ta bulunmuş ve üzerinde Leda motifi olan bir patera ile Ephesos'ta bulunan Medusa bezemeli bir örnek ise Misır buluntuları ile paralellik göstermektedir; Pastutmaz 2009: 49-50. 
pişirme sırasında 1sının iki katmana rahat nüfuz etmesi için açılan küçük deliklerin farklı yerlerde açılmış olmalarıdır. Aynı kalıplar kullanılarak üretilmiş bu iki seramik, oinophoros grubu içindeki pateraların üretim yerleri hakkında birkaç soruyu gündeme getirmeyi olanaklı kılmaktadır. Bu konuya değerlendirme bölümünde tekrar dönülecektir.

\section{Kat. No. 5 (Fig. 5)}

Kabın madalyon bölümü ve kaidesinin büyük bir bölümü; gövdenin ise çok küçük bir kısmı korunmuştur. Gövdenin korunan kısmından anlaşıldığı kadarıyla kabın dış yüzü yalın bırakılmıştır. Alçak halka kaidenin iç bölümündeki eş merkezli iki çıkıntılı halka, merkezde yer alan ikili rozet süslemesini çevrelemektedir. Madalyonda yer alan ve yüzeyi hafif aşınmış olan kabartma, en dişta üstü düz bir halka ve onun içinde kabaralardan oluşan bir çemberle sınırlandırılmıştır. Madalyonun üzerinde bulunan iki adet küçük delik, yukarıda da bahsedilen yapım tekniğiyle ilişkilidir. Kabartmada üç temel figür yer almaktadır. Sahnenin merkezinde, sağ tarafa yönelmiş bir panter yer almaktadır. Gövdesinin orta kısmından kırık olan panter figürü ön ayakları ileri uzanmış, hareketli bir şekilde tasvir edilmiştir. Baş kısmında kulak, göz, burun ve ağız bölümleri seçilebilmektedir. Panterin sırt bölümüne denk gelen alanda, gövdesinin alt bölümü eksik bir figür bulunmaktadır. Yuvarlak yapıda yüze sahip genç bir erkek olarak tasvir edilmiş figürün saçları, yan yana sıralanmış yuvarlak çıkıntılarla belirtilirken saçın sol kısmından figürün sol omuzunun üzerine bir üzüm salkımı sarkmaktadır. Boynunda, üzeri düz kolye benzeri kalın bir çıkıntı yer alır. Her ne kadar deformasyona uğramış olsa da panterin boyun gövde geçişinin üstüne uzanan sol elinde çift kulplu bir kap tutmaktadır. Bu figürün arkasında, omuzları hizasında yukarı doğru bir kavisle iki yana doğru açılan kanat benzeri motifler yer alır. Bu figürün sağ tarafında, yüzeydeki aşınmadan dolayı ayrıntılarını net olarak göremediğimiz yuvarlak yüze ve aşağ 1 doğru genişleyen uzun sakala sahip başlıklı bir figür yer almaktadır. Dionysos'un bir panter, 59 bir leopar, bazen bir kaplan veya aslan

59 Dionysos'un vahşi kediler ailesinin bir üyesiyle tasvir edildiği sahnelerde yer alan kedinin, bu geniş aile grubunun üyelerinden hangisi olduğunun teşhisi, özellikle anatomik ayrıntıların özenli yapılmadığ ile yer aldığı ikonografi, sıklıkla, onun doğanın vahşi güçlerini kontrol eden özelliğiyle ilişkilendirilir. ${ }^{60}$ Dionysos, bir panterle birlikte tasvir edildiği heykel gruplarında, kabartmalarda, duvar resimlerinde, mozaiklerde veya vazolar üzerindeki stilize resimlerde; pantere binerken, ${ }^{61}$ yaslanırken/yarı oturmuş halde, ${ }^{62}$ ayaklarının yanında duran ve/veya elindeki kantharostan şarap içen bir panterle ${ }^{63}$ ya da panterler tarafından çekilen bir araba içinde ${ }^{64}$ tasvir edilir. Ayrıca, Dionysos'un tören alayı betimlemelerinde yer bulan figürlerin panter postu giydikleri ve panter postunun çeşitli şekillerde bağımsız olarak birçok tasvirde yer aldığ 1 da görülebilmektedir. ${ }^{65}$ Tanrının, ele aldığımız madalyon üzerindeki varlığı, panterin hemen üzerinde konumlandığını gördüğümüz çocuk/ergen yaştaki figürün sol elinde tuttuğu bir kantharos ${ }^{66}$ ile saçlarının sol yanından omuzuna sarkan üzüm salkımı aracılığıyla açık bir şekilde anlaşılmaktadır. Bu bağlamda, Kat. No. 5 'in madalyonundaki kabartmada panter üzerinde çocuk/ergen yaşta Dionysos

eserlerde oldukça zordur. Bu nedenle metin boyunca, tasvirin ayrıntıları izin veriyorsa aslan, leopar ya da kaplan olarak tanımlanacak, ayrıntıların görülmediği durumlarda ise genel bir ifade olarak "panter" kelimesi kullanılacaktır. Roma İmparatorluk dönemi ikonografisinde kedigillerin tür ve cinsiyetleri üzerine bk. Jácome 2013: 526-540.

60 Dunbabin 1978: 174-175.

61 Robertson 1965: 76, Lev. 20, 1; Gasparri 1986a: 461, Kat. No. 430-434; Pollitt 1986: 216, Res. 230; MassaPairault vd.1979: 233-236, Res. III, 52 a-b.

62 Cristofani 1986: 532 Kat. No. 4; Gasparri 1986b: 548, Kat. No. 89; Erdoğan vd. 2018.

63 Gasparri 1986a: 435, 449-450, 473, 486, Kat. No. 119, 274, 598, 754; Gasparri 1986b: 542-545, 547-549, 555, Kat. No. 1, 13, 16, 19, 28, 42, 76, 79, 93, 103, 193, 201 a; Cristofani 1986: 535-536, Kat. No. 61; Augé 1986: 515-519, 522-523, Kat. No. 23, 27, 44, 81-82, 94, 120; Mandel 1988: 63, 68, Lev. 14, P 98.

64 Augé 1986: 528 Kat. No. 138; Gasparri 1986a: 463 Kat. No. 457. 458; Gasparri 1986b: 545 Kat. No. 47; Jácome 2013, 526, Res. 29.1. Panterler tarafından çekilen bir araba içindeki çocuk Dionysos tasviri için bk. Gasparri 1986b: 557, Kat. No. 175.

65 Gasparri 1986a: 438, 451, 457, 466, Kat. No. 141, 285, 374, 499; Augé 1986: 522, Kat. No. 84; Fathy 2019: 15-17.

66 Knidos’ta ele geçen ve küçük bir bölümü korunmuş patera tondosundaki kabartma, Patara örneğiyle yakın benzerlik içindedir. Knidos örneğinde pantere binmiş Dionysos'un sol elindeki kantharos oldukça belirgindir: bk. Pastutmaz 2009: 74, Res. 13 c; Pastutmaz 2011: 98, Lev. 15, 2. 
ikonografisinin konu edildiğini söylememiz mümkün görünmektedir. ${ }^{67}$

$\mathrm{Bu}$ noktada üzerinde durmamız gereken önemli hususlardan biri, Patara örneğinde tanrının arkasında her iki yana açılan ve yukarı doğru kavisle yükselen dörder ince hattan oluşturulmuş motifin tanımlanmasidır. Bu motifin, kompozisyon içindeki konumu ve görünümü her ne kadar simetrik bir yapıda olmasa da bir çift kanat olma ihtimalini düşündürmektedir. Bir diğer olasılık ise Dionysos'un panteri sürerken rüzgârla savrulan chlamys/pelerini olabileceğidir. Dionysos'un boyun çevresinde yer alan yarı dairesel kolye benzeri motifin tanımlanması bu noktada önem kazanmaktadır. Knidos'ta ele geçen bir patera tondosu üzerindeki kabartma hem kompozisyon hem de stil açısından Patara örneğiyle oldukça yakın benzerlik göstermesi açısından bu konuda küçük de olsa ipuçları sunar. ${ }^{68} \mathrm{Bu}$ örnekte, tanr1nın boynundaki yarı dairesel motifin küçük nokta ve çentiklerle süslendiği ve küçük bir çelenk/ girland olduğu görülebilmektedir. Dolayısıyla, iki yana uzanan bu motifin herhangi bir kism1nın Dionysos ile hiçbir bağlantısının olmadığ 1 anlaşılmakta ve motifin bir pelerin olma olasıllı̆ 1 geri planda kalmaktadır. Tüm bu ayrıntılar, Patara örneğindeki kabartmada "kanatlı Dionysos" betimlenmiş olabileceğini ihtimaller dâhiline almamız gerektiğini göstermektedir. 69

67 Bir panter üzerindeki Dionysos ikonografisinin varyant1 olarak değerlendirebileceğimiz, Dionysos'un bir vahşi kedi üzerinde çocuk/ergen yaşta tasvir edildiği bu ikonografi, Memphis’teki Serapeion heykelleri (Massa-Pairault vd. 1979: 233-236, Res. III, 52 a-b) kadar erken bir tarihte bağımsız bir grup olarak ortaya çıkmış ve oldukça sık yinelenen bir tasvir olarak Roma İmparatorluk Dönemi’nde de varlığını sürdürmüştür; bk. Dunbabin 1978: 175; Erdoğan vd. 2018: 288-289. Bir panter, kaplan ya da leopara binmiş çocuk Dionysos tasvirleri için bk. Weber 1892: 290, Lev. 23 (Eros), karş. Erdoğan vd. 2018, 289-290 (Dionysos); Robertson 1965: 76, Lev. 20, 1; Dunbabin 1978: 175-178, Res. 174-177; Parrish 1981: 55; Augé 1986, 524, Kat. No. 102; Jácome 2013, 537, Res. 29.; Erdoğan vd. 2018.

68 Pastutmaz 2009: 74, Res. 13 c; Pastutmaz 2011: 98, Lev. 15, 2.

69 Pausanias, Lakonia kenti Amyklai'de tapınılan tanr1lardan birinin, o kentte " $\psi 1 \lambda \alpha \xi$ " - "psilaks" epitethiyle anılan Dionysos olduğunu ve bu kelimenin kanat anlamında kullandığını belirtmektedir. Ardından, şarabın, insanı canlandırdığı ve ruhlarını kanatların kuşlara yaptığı gibi, yükselttiğini söyleyerek bu sıfatın Dionysos'a uygun olduğunu söylemektedir (Pausanias 3, 19, 6). Kanatlı Dionysos ikonografisi için
Panter üzerinde tasvir edilmiş çocuk/ergen "kanatlı Dionysos" tasvirlerinin ayırt edici özelliklerinden biri kanatlı Eros’a özgü resimsel özelliklere sahip olması ve sarmaşı dalları, thyrsos ve kantharos gibi Dionysos'a has niteliklerle bir araya gelerek bir Dionysos-Eros birleşimi gibi görünmesidir. ${ }^{70}$ Delos'taki Dionysos Evi'nin impluviumunu süsleyen mozaikte, bir kaplana binen genç yaşlarda kanatlı bir Dionysos tasvir edilmiştir. $^{71}$ MÖ 2. yüzyıla tarihlendirilen bu mozaik üzerinde zarif bir genç yüze, büyük açık gözlere, hafif açık dudaklara ve sarmaşıklarla süslenmiş bir başa sahip Dionysos, sağ elinde bir thyrsos tutmakta ve kaplanın hemen önünde yer alan kantharos da Dionysos'un bir göstergesi olarak sahnede yer bulmaktadır. ${ }^{72}$ Bir diğer örnek, Pompeii'deki Faun'un Evi olarak adlandırılan villanın yemek odasının (triclinium 34) zeminini süsleyen mozaiktir. Girlandların, sarmaşıkların ve tiyatro masklarının süslediği zengin bir çerçeveyle çevrelenen bu mozaiğin merkezinde, boynunda sarmaşıklar ve üzüm salkımları bulunan, aslan yelesine sahip bir kaplanın(?) sirtına binmiş kanatlı çocuk figürü görülmektedir. Başında sarmaşık dallarından bir taç bulunan bu kanatlı çocuk figürü sağ eli ve koluyla kavradığı kantharostan şarap içmek üzere başını eğmiş bir şekilde tasvir edilmiştir. Kaplanın(?) ön ve arka ayaklarının arasında ise bir thyrsos yer almaktadır. MÖ 2. yüzyıla tarihlendirilen mozaikteki bu figürün kanatlı bir Dionysos'u temsil ettiği, sahnedeki Dionysos'a işaret eden sarmaşıklardan oluşan taç, kantharos ve thyrsos gibi atribütlerden anlaşılmaktadır. ${ }^{73}$ Delos ve Pompei'deki mozaiklerden yüzyıllar sonra yapılmış Konstantine

bk. Farnell 1909: 253; Picard 1935, 317; Jonas 1960: 8; Screech 1980; Gasparri 1986a: 414, 440, 498, Kat. No. 152; Gasparri 1986b: 559, Kat. No. 258; Pollitt 1986: 216, Res. 231; Dunbabin 1999: 33, Res. 33; Pailler 2000: 381, Res. 1; Stone 2014: 254-255, Lev. 113, 540-541.

70 Pesando 1996: 213-214.

71 Bruneau 1972: 248-253; Pollitt 1986: 216, Res. 231; Dunbabin 1999: 33, Res. 33.

72 J. J. Pollitt, mozaikteki figürün kimliğinin tamamen açık olmadığını, bununla birlikte doğrudan Dionysos kültü ve mitleriyle ilişkili olduğunu belirtmektedir; bk. Pollitt 1986: 216.

73 Mozaik ilk olarak keşfedildiğinde "Il Genio di Bacco" olarak isimlendirilmiştir; bk. Blake 1930: 137138. M. M. Bulard, Delos Dionysos Evi'ndeki mozaiği incelerken, Pompei mozaiğindeki figürü Dionysos olarak kabul eder; bk. Bulard 1908: 199-203. Ayrica bk. Gasparri 1986b: 559, 561 Kat. No. 258; Pesando 1996: 213-215. 
kentinden bir mozaik de benzer bir ikonografi taşır. MS geç 3. yüzyıl - 4. yüzyıla tarihlendirilen mozaiğin merkezinde, büyük bir kanthorosa yönelmiş bir leopar yer almaktadır. Leoparın gövdesinin orta bölümü de dahil olmak üzere tahrip olmuştur. Ancak korunmuş küçük bir bölümde, leoparın sırtında oturan bir figürün birbirine paralel yapılmış dört tüyden oluşan bir kanadının ucu, eliyle tuttuğu dizginler ve bir kırbaç görülebilmektedir. Böylelikle leoparı kantharosa yönlendiren küçük bir kanatlı figürün varlığı anlaşılmaktadır. Mozaiğin alt bölümünde, merkezdeki sahneye oranla çok daha küçük yapılmış ve elinde syrinks bulunan bir satyr yer almaktadır. Figürün kendisinin neredeyse tamamen tahrip olduğu Konstantine mozaiğinde, bunun Eros için mi, "kanatlı Dionysos" için mi tasarlandığını söylemek zordur. Ancak, Delos ve Pompei mozaiklerinde olduğu gibi burada da Dionysos kültüyle olan ilişki açıktır. ${ }^{74}$

Panter üzerinde, çocuk veya genç olarak tasvir edilmiş kanatlı figürlerin kimliğinin tespiti, kapsamlı ama bir o kadar da ucu açık tartışmaları beraberinde getirmiştir. Genel eğilim, Dionysos'u işaret eden sarmaşıktan taç, thyrsos, kantharos gibi özel nesnelerin veya satyr gibi Dionysos kültüyle ilişkili figürlerin bulunduğu durumlarda "kanatlı Dionysos"un tasvir edildiğine yöneliktir. Bu figürün, daha nadir ve daha temkinli bir şekilde "Dionysos Demon"u olarak isimlendirildiği de görülmektedir. ${ }^{75}$ F. Pesando, Dionysos'un atribütleri ile Eros'un resimsel özelliklerinin bir karışımı ya da iç içe geçmesiyle oluşturulmuş bu tasvirin, Hellenistik doğuda özellikle Misır'da takip edilebileceğini; Aphrodite-Ariadne ve Dionysos arasındaki "hieros gamos"un bir temsili olarak görülebileceğini belirtmektedir. ${ }^{76}$ Patara

74 Dunbabin 1978: 178, Res. 174.

75 Pernice 1938: 158-159.

76 Pesando 1996: 214-215. Ptolemaios hanedanının kralları, tüm Hellen tanrılarından Dionysos ile özel bir ilişkiye sahip olduklarını iddia etmişler ve kendilerini çoğu zaman onunla eş görmüşlerdir (Ager 2006: 178), ayrıca en azından MÖ 5. yüzyıldan itibaren Hellenler (ve Misırlılar) Dionysos'un Osiris ile eşitliğini kabul etmişlerdi (Hdt.: 2, 42; Diod. Sic.: 1, 13). Bununla birlikte, Ptolemaios kraliçeleri, en azından II. Arsinoe'den itibaren geleneksel olarak Aprodite yani İsis ile ilişkilendirilmiştir (Ager 2005: 24-25). VII. Kleopatra ile Marcus Antonius'un MÖ 41 yılında Tarsus'a gelişlerinin halk arasında "Aphrodite'nin Dionysos'la birlikte, Asia'nın iyiliği için eğlenmeye/ şenlik yapmaya" geldikleri şeklinde yayılması da bu gibi Mısır ile yüzyıllarca yoğun ilişki içinde olan bir kentte, Roma İmparatorluk Dönemi'nde devam ettiğini bildiğimiz bu ikonografinin görünmesi, çok da şaşırtıcı olmamalıdır.

Madalyondaki kabartmada, Dionysos'un sağındaki figürün oldukça tahrip olsa da yukarıda da tanımladığımız gibi yuvarlak yüzlü, aşağıya doğru genişleyen uzun sakallı bir figür olduğunu belirtmiştik. Yüzdeki ayrıntıların görünmemesi bu figürü tanımlamamızı zorlaştırsa da genel hatlar Pan ya da Bes olması gerektiğine işaret etmektedir. ${ }^{77} \mathrm{Bu}$ figürün Pan olduğunu düşünürsek Dionysos, panter ve Pan'ın yer aldığ kompozisyonların Dionysos ikonografisinin bilinen örnekleriyle uyum içinde olduğunu söyleyebiliriz. ${ }^{78}$ Bir diğer yandan Misır tanrısı Bes'in de Dionysos dünyasıyla iç içe geçtiği hatta çağlar boyunca süzülen Bes inancının, Pan ve Dionysos gibi kültlerle sonuçlandığı görülmektedir. Tanrı Bes'in birçok kez Dionysos ile bağlantılı sahnelerde ona eşlik ettiğinin görülmesi, onun Dionysos çevresine yabanc1 olmadığını göstermektedir. ${ }^{79} \mathrm{Bu}$ noktada, olası bir Mısır bağlantısının yeniden ortaya çıkabileceği olanaklı görünse de bu figürün teşhisinin net olmadığını belirtmemiz gerekmektedir.

Yukarıda da bahsedildiği gibi, Knidos'ta ele geçen bir patera madalyonundaki kabartma hem kompozisyon hem de stil açısından Patara örneğiyle oldukça yakın benzerlik göstermektedir. Knidos örneği MS 1. yüzyıla tarihlendirilmektedir. ${ }^{80}$ Meclis - Kuzey Sur çalışmalarında, MÖ 1. yüzyıl ile MS 5. yüzyıla arasına tarihlendirilen buluntuların bulunduğu bir katmandan ele geçen Kat. No. 5, Knidos örneği aracılığıyla MS 1. yüzyıla tarihlendirilmektedir.

\section{Kat. No. 6 (Fig. 6)}

Büyük bir bölümü eksik olan parçanın, kaidesinin iç kısmında dört adet eş merkezli daire içinde ikili rozet motifi yer alır. Diğer örneklerden farklı olarak, iç rozet ile diş rozetin birleşme yerlerinde bir seri kabara dairesel bir hat oluşturacak

eşleşmenin devamlılığını gösteren örneklerdendir; bk. Plut. Ant. 26.

77 Oinophoros grubu testiler üzerindeki kabartmalarda da Pan karşımıza çıkmaktadır; bk. Mandel 1988: 151152, Lev. 25, K 6.

78 Tulunay 2005: 24-25, Res. 6.

79 Tinh 1986: 108, Kat. No. 83; Pons 1997: 106, Kat. No. 19.

80 Pastutmaz 2011: 98, Lev. 15, 2. 
şekilde yerleştirilmiştir. Madalyon bölümündeki kabartmada, gövdesinin üst bölümü korunmamış bir kadın figürünün baldırından itibaren bacaklar1 görülebilmektedir. Olasılıkla bir kaya üzerine oturmuş figürün bacakları profilden, sağ ayağ1 ise cepheden işlenmiştir. Sağ ayağın bastığı yükseltideki ayrıntılardan figürün bir kumaş parçası üzerine oturduğu/uzandığı anlaşılmaktadır. Kabartmanın diğer kısmında, kadın figürün karşısında ise aşağ 1 doğru gittikçe incelerek üçgene yakın bir form alan ve üzerinde nerdeyse birbirine paralel yivlerin bulunduğu bir figür yer almaktadir.

Oinophoros grubu içinde, özellikle patera madalyonlarında erotik sahnelerin de yer aldığ mektedir ${ }^{81}$. Kat. No. 6'da da böyle bir sahnenin işlenmiş olduğunu düşünebiliriz. Kadın figürün karşısındaki yivlerin uca doğru sivrilen bir kanat gibi sınırlandırılması, Leda ve kuğu kılığ1na girmiş Zeus ikonografisinin kullanılmış olabileceğini düşündürmektedir. Geç Hellenistik Dönem'de görülmeye başlanan bir ikonografik anlatım, ${ }^{82}$ Leda'yı bir yatağı veya bir kayayı kaplayan kumaş üzerinde tamamen çıplak bir şekilde uzanmış olarak gösterir. Bu ikonografide Leda, bir koluna yaslanmış ve diğer koluyla kucakladığ1 kuğunun gagasını öpmek için öne doğru hareketlenmiş bir pozisyondadır. Kuş genellikle Leda'nın dizden bükülmüş ya da havaya kaldırılmış bacaklarının arasında yer alır. ${ }^{83}$ Kanatlar açık veya aşağı sarkık bir şekilde yarı kapalı tasvir edilmektedir. ${ }^{84}$ Patara örneğinde de Leda'nın bir kaya üzerindeki kumaşa uzandığ 1 ve karşısındaki yivlerle bezenmiș üçgen bölümün kuğunun yarı açık ve aşağ 1 uzanmış kanadı olduğunu düşünmek akla yatkın gibi görünmektedir. Roma İmparatorluk Dönemi'nde hatırı sayılır bir şekilde revaçta olan bu ikonografinin Geç Antik Dönem'e kadar kullanıldığı görülmektedir. ${ }^{85} \mathrm{Li}$ man Caddesi Batı Portikus buluntularından olan patera (Kat. No. 6), MS 1-4. yüzy1l tabakasından ele geçmiştir.

81 Mandel 1988: 168-171.

82 Breccia 1909: 317, Res. 66; Mandel 1988: 135-136; Kahil 1992: 246.

83 Kahil 1992: 242-244, 246, Kat. No. 110-121, 126-135.

84 Kahil 1992: 244, 246, Kat. No. 130. Knidos'ta ele geçen Leda-Zeus kabartmasına sahip patera madalyonları için bk. Pastutmaz 2009: 88-90, Res. 19-20.

85 Mandel 1988: 135-136; Kahil 1992: 246.

\section{Kat. No. 7 (Fig. 7 )}

Küçük bir bölümü korunmuş kabın halka kaidesinin iç bölümünde dört adet eş merkezli daire içinde ikili rozet yer almaktadır. Kabın gövdesinin iç ve dış yüzü yalın bırakılmıştır. Madalyonun korunmuş bölümünde dizin alt kısmı korunmuş bir bacak ve onun önünde hafif S kıvrımlı yivlerle hareketlendirilmiş aşağ ${ }_{1}$ sarkan giysi ayrıntıları görülmektedir. Figürün açıkta kalan bacağı dizden hafif kıvrılmış ve parmak ucuyla, kabartma olarak hazırlanmış zemin üzerine basmaktadır. Bu zeminin altında ise çam kozalağına benzer bir motif yer almaktadır. Kabartmanın muhtelif yerlerinde, toplam beş adet havalandırma deliği bulunur.

Kabın kırık madalyon bölümündeki figürün teşhisi oldukça zordur. Ancak yine de hareketli elbise kıvrımlarının oinophoros grubu kapların kabartmalı süslemelerinde sıklıkla karşımıza çıkan, dans eden ya da bir müzik aleti çalan maenad figürlerini hatırlattığını söyleyebiliriz. ${ }^{86}$ Tanrı Dionysos'un ve onun dünyasıyla ilgili figürlerin s1klıkla tasvir edildiği oinophoroslarda maenadların da sıklıkla yer bulması son derece olağan kabul edilmelidir. ${ }^{87}$ Maenad figürlerinin görüldüğü Pergamon ve Knidos örnekleri MS 2. yüzyıla tarihlendirilmektedir. ${ }^{88}$ Bununla birlikte, Patara Kent Kapısı'nın 50 m güneyinde konumlanan Sekizgen Çeşme çalışmalarında tarım toprağ 1 içinde bulunan Kat. No. 7'nin buluntu durumu nedeniyle, spesifik bir tarihlendirme önerisinde bulunulamamaktadır.

\section{Kat. No. 8 (Fig. 8)}

Kaidesinin ve madalyonun bir bölümü korunmuş kabın, kaidesinin iç kısmında dört adet eş merkezli halka ile çevrelenmiş bir rozet yer almaktadır. Madalyonun dış kısmı, küçük kabaralardan oluşmuş dairesel bir bantla çerçevelenmiştir. Madalyonda yer alan figür, kol altından kırık ve eksiktir. Madalyonun kabartmalı süslemesindeki bu figürün, yüzü cepheden; kolları ve vücudu öne doğru harekete uygun olarak profilden işlenmiş, arkada kanatlarının bir kısmı korunmuş Eros olduğu açıktır.

\footnotetext{
86 Mandel 1988: 64-65, 149-150, Kat. No. K 70, K 71, P 7, P 36, P 98; Lev. IV, 1-3; Pastutmaz 2009: 104-106, Res. 40-42.

87 Pastutmaz 2009: 104.

88 Mandel 1988: 108.
} 
Oinophoros grubu seramiklerin pek çok türünde Eros'un da çeşitli sahnelerde yer aldığı görülmektedir. Eros'un bu kabartmalarda genelde, kalabalık sahnelerde tamamlayıcı bir figür olarak yer aldığı görülmektedir. ${ }^{89}$ Ender de olsa, Knidos'ta ele geçen bir patera tondosunda olduğu gibi tek başına ${ }^{90}$ ya da yine Knidos'ta ele geçen iki örnek de olduğu gibi çevresinde asma dalları ve üzüm salkımlarıyla bağbozumu sirasında ${ }^{91}$ bulunduğu örnekler bulunmaktadır. Tepecik Nekropolü'nde dolgu/akıntı toprak içinde ele geçen Kat. No. 8'de yer alan Eros'un saç, yüz ve kanatlarının işlenişi açısından benzerlik gösteren Knidos örnekleri MS 2. yüzyıla tarihlendirilmektedir.

\section{Kat. No. 9 (Fig. 9)}

Madalyon, kaide ve gövdenin bir bölümünün korunduğu Kat. No. 9'un, alçak halka kaidesinin iç kısmında dört adet dışta yuvarlatılmış forma sahip eş merkezli daireyle çevrelenmiş rozetin bir bölümü görülebilmektedir. Madalyonun çevresi, ortalarında noktalar bulunan bir dizi kabarayla sınırlandırılmıştır. Korunmuş bölümlerden bu çevre bandına kadar uzanan rozet yaprakları ve onun içinde sarmaşık yapraklarından oluşan bir serinin bulunduğu görülebilmektedir. Kabartmanın farklı yerlerinde üç küçük havalandırma deliği bulunmaktadır.

Kabartmanın merkezinde yer alan figürle ilgili hiçbir detay görünmese de sahnenin Dionysiak bir anlatıma sahip olduğu anlaşılmaktadır. İskenderiye'den iki patera madalyonu üzerinde, cepheden işlenmiş bir genç erkek yüzünün çevresi, alından boyuna kadar sarmaşık yaprakları ve çiçeklerle taçlandırılmış ve çevrelenmiştir. ${ }^{92}$ Burada işlenen kalın kalp şeklinde yapraklara sahip sarmaşıklar, Patara örneğiyle stil açısından uyum göstermektedir. Olasılıkla Patara örneğinde de İskenderiye örneklerinde olduğu gibi cepheden işlenmiş ve sarmaşıklarla çevrili bir Dionysos yüzü kabartmayı oluşturmuş olmalıdır. 93

Patera (Kat. No. 9), Meclis - Kuzey Sur çalışmalarında, MÖ 1. yüzyıl ile MS 5. yüzyıla arasına

89 Mandel 1988: 166-168; Pastutmaz 2009: 96-98.

90 Pastutmaz 2009: 96, Res. 29.

91 Mandel 1988: 112-113, Kat. No: Lev. 31, K 125; Pastutmaz 2009: 96-97, Res. 30, 32.

92 Breccia 1909: 309-310, Res. 55-57.

93 Oinophoros grubu bir pelike üzerindeki Dionysos büstü için bk. Heimberg 1976: 287, Res. C15; Mandel 1988: 113, Kat. No. K 48. tarihlendirilen buluntuların bulunduğu bir katmandan ele geçmiştir. İskenderiye örnekleri arac1lığıyla MS erken 3. yüzyıla tarihlendirilmektedir.

\section{Kalıp ${ }^{94}$ - Kat. No. 10 (Fig. 10)}

Tepecik Nekropolü'nde yüzeyde ele geçen kalıbin yaklaşık dörtte biri korunmuştur. ${ }^{95} \mathrm{Bu}$ korunan bölümden, dairesel bir forma sahip olduğu anlaşılmaktadır. Çevresi üçlü bantla sınırland1rilan kalıbın merkezinde yer alan sahnenin korunmuş bölümünde, ayakta duran ve himation giymiş bir erkek figürünün gövdesinin alt bölümü görülebilmektedir. Hemen yanında görülen ince uzun bir hat bir asaya ait olabilir. Bu asadan kurdele benzeri dalgalı bir motif sarkmaktadır. Figürün ayaklarının hemen yanında ise bir çam kozalağ 1 motifi yer almaktadır.

Sahnede yer alan bazı detaylar, bu kalıp üzerinde yer alan figürün kimliği hususunda öneriler getirmemize yardımcı olacak niteliktedir. Ayakta duran figürün yanındaki asa ve çam kozala$\breve{g} 1$ motifi bize ipucu verebilir. Asanın hemen yanından sarkan kurdele (taenia) benzeri motif, bu asanın Dionysos'un simgelerinden biri olan "thyrsos" olabileceğini akla getirmektedir. ${ }^{96}$ Ayrıca, çam kozalakları Dionysos'un başta gelen atribütlerinden biri olan "thyrsos" nedeniyle, antik literatürde de değinildiği gibi, genelde Dionysos ile ilişkilendirilmektedir. ${ }^{97}$ Çam kozalağı genellikle thyrsosun uç kısmında karşımıza çıkmakla birlikte, bazen tanrının elinde tek başına ya da Dionysos dünyasına ait figürlerin yer aldığ tasvirli sahnelerde de görülebilmektedir. ${ }^{98} \mathrm{Genel}$

94 Kat. No. 10 kodlu kalıp parçası, ilk olarak, II. Uluslararası Sosyal Bilimlerde Kritik Tartışmalar Kongresi / II. International Congress on Critacal Debates in Social Sciences başlıklı kongrede sunulmuş ve tam metin bildiri kitabında yer almıştır. Ancak, bu kongrenin bildiriler kitabında gerçekleşen bir dizgi hatası nedeniyle eserin fotoğrafı yer almamıştır; bk. Şahin 2019.

95 Kalıbın orijinal halinde yaklaşık 10-12 cm çapında olmasi gerekmektedir.

96 Pek çok farklı thyrsos türü vardır. Yazınsal ve resimsel tanımlamalar için bk. Papen 1905.

97 Pinckernelle 2007: 32.

98 Ovadiah 2012: 92, 101, Res. 1. St. Petersburg Devlet Hermitage Müzesinde MS 2. yüzyıla tarihlendirilen bir Dionysos heykelinde, tanrı bir elinde üzüm salkımı diğer elinde ise çam kozalağ tutmaktadır (ГР3004). "Art Works 2019" (hermitagemuseum.org). Her ne kadar çam kozalağı, antik dünyanın farklı bölgelerinde Sabazios ya da Attis kültü gibi çeşitli 
olarak oinophoros grubu kap formlarının kabartmalı sahnelerinde özelde ise pateraların tondolarında yer alan tasvirlerde birçok farklı mitolojik figür işlenmiş olsa da Dionysos'un ve Dionysos kültüyle ilgili figürlerin ağırlıklı olarak yer tuttuğu görülmektedir. ${ }^{99}$ Böylelikle hem kalıbın formu hem de işlenen konu, Patara'da oinophoros grubu kaplardan özellikle pateraların üretilmiş olup olamayacağ 1 sorusunu akla getirmektedir. $\mathrm{Bu}$ noktada kalıp üzerindeki önemli bir ayrıntı ön plana çıkmaktadır. Yukarıda da bahsedildiği gibi, Patara'da ele geçen kalıbın merkezinde yer alan sahnenin çevresi, üçlü yalın bantlarla sınırlandırılmıştır. Genel olarak, pateraların madalyonlarında yer alan kabartmalı sahnelerin; bazen bir dizi kabara, spiral veya daireyle oluşturulmuş bantlarla ${ }^{100}$ ya da tekli, ikili, üçlü veya dörtlü yalın bantlarla çevrelendiği görülmektedir. ${ }^{101} \mathrm{Bu}$ bağlamda kalıbın hem dairesel bir baskı alanı için üretilmiş olması hem de çevresindeki bantlar, bir patera tondosunu biçimlendirmek için son derece uygun bir yapıda olduğunu göstermektedir.

\section{Genel Değerlendirme}

Çalışma konusunu oluşturan oinophoros kabartmalı seramikleri içinde bir amphora, sekiz patera parçası ve bir kalıp bulunmaktadır. Bu buluntular, antik kentte, Meclis - Kuzey Sur çevresi, Tepecik Nekropolü, Liman Caddesi Batı Portikosu, Nero Hamamı, Sekizgen Çeşme ve Su Yolu sondaj çalışmaları gibi farklı alanlardan ele geçmiştir. Oinophoros grubu kap tiplerinin çoğunun doğru tarihlendirilebilmesi için stratigrafik kanıtlara ihtiyaç duyulmaktadır. Ancak, Patara örneklerinin bulundukları tabakaların farklı dönemlere ait pek çok buluntu içermesi kontekst aracılığıyla tarihlendirmeyi zorlaştırmaktadır. Benzer örnekler ve/veya stil değerlendirmesi aracılığıyla MS 1. yüzyıla (Kat. No.

kültlerde de simgesel olarak yer bulmuş olsa da Dionysos kültü içinde doğrudan yer bulmakta ve daha çok onunla ilişkilendirilmektedir; bk. Masoud 2015: 43.

99 Salomonson 1979: 118; Mandel 1988: 62-73, 149-157; Pastutmaz 2011.

100 Breccia 1909: 309-310, Res. 56, 58; Love 1969. 218, Res. 20; Salomonson 1979: 119, Res. 7; Pastutmaz 2009: 89, 97, Res. 19, 32.

101 Breccia 1909, 308-311, Res. 54, 59, 60, 63; Salomonson 1979, 118, 122, Res. 2, 13; Pastutmaz 2009: 46, Res. 7, 13, 17, 21.
5), MS 1-2. yüzyıla tarihlendirilen (Kat. No. 2, 3,8 ) ve MS erken 3. yüzyıla ait örnekler (Kat. No. 1, 4, 9) saptanabilmektedir. Bununla birlikte, diğer buluntular (Kat. No. 6, 7) genel olarak Roma İmparatorluk Dönemi'ndeki MS 1. yüzyıl ile MS 3. yüzyılın ilk yarısı arasında devam ettiği bilinen oinophoros üretim süreci içinde değerlendirilmektedir.

Oinophoros grubu seramiklerin geniş konu repertuarı içinde, mitolojik sahnelerde yoğun olarak Dionysos kültüyle ilişkili anlatımlar yer almaktadır. Bununla birlikte, Zeus'la bağlantılı; Kuğu-Leda ve Kartal-Ganymedes mitosunda konu alındığ 1 ya da Aphrodite'yle ilgi sahnelerde görülebildiği gibi diğer tanrı ve tanrıçalarla bağlantılı mitoslar da kabartmalı sahnelerde yer bulmuştur. Herakles'in işleri ya da amazonmakhia gibi mitoslar da bu repertuar içinde sıklıkla yer bulmuştur. Bir amphora (Kat. No. 1) haricinde çoğunluğunu pateraların (Kat. No. 2-9) oluşturduğu Patara oinophoros grubunun kabartmalı sahnelerinde tanımlanabilen konuların da yukarıdaki mitolojik karakteri sürdürdügü görülmektedir. Kartal kılığındaki Zeus ile Ganymedes'in işlendiği bir amphora (Kat. No. 1), kuğu kılığına girmiş Zeus ve Leda mitosunun konu edildiği bir patera tondo parçası (Kat. No. 6), yaygın olarak kullanılan bu sahnelerin Patara'daki örneklerini oluşturmaktadır. Küçük bir parçası korunmuş bir madalyonda ise Aphrodite ile birlikte anılan Eros görülebilmektedir (Kat. No. 8). Bu örneklerin yanı sıra, Patara örneklerinde Dionysos kültüyle bağlantılı tasvirler yoğunluk göstermektedir. Olasilıkla Dionysos alayından bir sahnenin yer aldığ1 madalyon üzerindeki dans eden maenad'a ait parça (Kat. No. 7), dans eden figürlerin de yer aldığ 1 bir patera madalyonu (Kat. No. 2), sarmaşı yapraklarıyla çevrelenmiş ve İskenderiye'den örnekler aracılı̆̆ıyla cepheden bir Dionysos yüzü tasviri taşıdığı düşünülen madalyon (Kat. No. 9) ve çocuk/ergen yaşta "kanatlı Dionysos"un bir panter üzerinde tasvir edildiği madalyon (Kat. No. 5), Dionysos kültüyle bağlantılı olarak Patara'daki oinophoros grubu pateraların süslemelerinde yer bulmuştur. Özellikle yukarıda ayrıntılı olarak ele aldığımız çocuk/ergen yaşta tasvir edilen "kanatlı Dionysos" un bir panter üzerindeki betimlemesi, Antik Dönem'de az bilinen bir ikonografinin karşımıza çıkması açısından önemlidir. Bu, üretim ve ticari ağların yanı sıra ortak inançların/düşüncelerin geniş iletişim ağını göstermesi açısından da önemli örneklerden birini teşkil etmektedir. 
Oinophoros grubunun ilk üretim yeri olan Knidos'ta ele geçen kabartmalı seramikler ile Patara örnekleri arasında stil açısından yakın bir ilişki olduğunu gösteren örnekler mevcuttur. Amphora üzerindeki Zeus-Ganymedes ikonografisi (Kat. No. 1), Knidos'ta ele geçen ve çok daha küçük bölümü korunmuş bir örnekle yakın stil özellikleri taşımaktadır ${ }^{102}$. Herakles Girit Boğası mücadelesinin konu edildiği madalyonun (Kat. No. 4) birebir aynı kalıp kullanılarak yapılmış bir örneği İskenderiye'de tespit edilmiştir. ${ }^{103}$ Knidos kazılarında ele geçen bir madalyon parçasında korunmuş profilden Herakles başının da Patara ve İskenderiye örnekleriyle oldukça yakın stilde işlendiği görülmektedir. ${ }^{104}$ Panter üzerinde çocuk/ergen "Kanatlı Dionysos" ikonografisinin yer aldığ küçük bir bölümü korunmuş bir benzeri de yine Knidos atölyelerinde üretilmiştir. ${ }^{105}$

Elimizdeki örnekler Patarai Knidos ve Misır arasında bir iletişimin açık olduğunu göstermektedir. Akdeniz ticaret yolları üzerinde önemli liman kentleri olan Patara 106 ve Knidos'un, ${ }^{107}$ Ptolemaios I Soter'in MÖ 288/87 yılında Anadolu'nun güneybatı kıyılarına hâkim olduğu süreçten itibaren İskenderiye'yle yakın ilişkileri hem yazınsal hem de arkeolojik veriler aracılığıyla yakından bilinmektedir. ${ }^{108}$ Bu yakın ilişki, sadece, askeri ve ekonomik alanda değil kültürel ve dini açıdan da ortak düşüncelerin karşılıklı alışverişini sağlamış olmalıdır ki oinophoros grubu pateraların taşıdığı kabartmalarda da benzer ikonografilerin yaygınlıği takip edilebilmektedir. Ptolemaios II Philadelphos Patara'yı onurlandırmak için kente kız kardeşi/eşi II. Arsione'nin ismini verirken 109 bu süreçte Mısır tanrıları inanc1 kentte yayılarak Roma İmparatorluk Dönemi içlerine kadar devam etmiştir. ${ }^{110}$ Ptolema-

102 Pastutmaz 2009: 83-88, Res. 16.

103 Breccia 1909: 364, Res. 61.

104 Pastutmaz 2009: 104, Res. 38.

105 Pastutmaz 2009: 74, Res. 13 c.

$106 \mathrm{Kaz}$ sonuçlarına yönelik bir güncel durum değerlendirmesi için bk. İşkan (Ed.) 2019.

107 Doksanalt1 2006: 195-197.

108 Wörrle 1977: 44, 47, 57.

109 Strab. 14, 3, 6.

$110 \mathrm{Bu}$ dönem içinde tanışılan Mısır mistisizmi ve kültleri Patara'da mezarlarda ele geçen İsis ve Harpokrates kültlerine ait terrakotta heykelciklerle de desteklenmektedir; bk. Işıı 2007: 4, 46,-47, 74-76, Kat. No. 21, 41, 42. ios II Philadelphos, Knidos’taki dini şenliklere destek vermiş, Apolllon Karneios şenliklerini tekrar canlandırmaya yönelik faaliyetlerde bulunmuştur. Bununla birlikte, bu süreçte Knidos Aphrodite Euploisa ile Mısır tanrıçalarından İsis kentte eşit olarak görülmüştür. ${ }^{111} \mathrm{Bu}$ bağlamda, öncelikle Kat. No. 6'da bir panter üzerinde tasvir edilmiş çocuk/ergen "kanatlı Dionysos" betimlemesindeki Dionysos'un, Eros'a özgü ikonografik özelliklerle ve Dionysos'un atribütleriyle donatılmış olmasının; kökleri özellikle Hellenistik Dönem Mısır'ında takip edilebilen İsis - Aphrodite ve Osiris - Dionysos özdeşleştirmesinin bir yansıması olarak görülebilir. Böylelikle Misır'la bağlantılı olarak görülen çocuk/ergen "kanatlı Dionysos" ikonografisinin de İskenderiye ile kültürel ve dini alışverişi yüzyıllar boyunca sürmüş Patara ve Knidos'taki varlığ biraz daha makul ölçülerde açıklık kazanabilmektedir. İskenderiye'de aynı kalıptan üretilmiş bir eşi bulunan Herakles Girit Boğası mücadelesinin konu edildiği örneklerdeki Herakles'in Knidos örnekleriyle stilistik olarak yakın ilişki içinde olması ise Knidos üretimi olan bu parçanın her iki kente de ihraç edilmiş çok sayıda kopyadan ikisi olarak açıklanabilir. Ancak bu noktada Patara'da ele geçen bir kalıbı da üretim merkezleri odağında değerlendirmemiz gerekmektedir.

Oinophoros grubu kaplar üzerine yapılan araştırmalar, bu grubun ilk olarak Erken Roma İmparatorluk Dönemi'nde Knidos'ta üretilmeye başlandığını göstermektedir. ${ }^{112}$ Bunun yanı sıra, bu seramik grubunun Akdeniz çevresinde oldukça popüler bir ürün haline gelmesiyle birlikte hem Pergamon'daki113 (MS 1. yüzyıl ortaları) hem de İasos’taki atölyelerin ${ }^{114}$ (MS 2. yüzyılın ikinci yarıs1), oinophoros kaplarını üretmeye başladıkları görülmektedir. Knidos'taki oinophoros üretiminin MS 3. yüzyılda azalmaya başladığı ve bu süreçte Kuzey Afrika atölyelerinde üretimin arttığı bilinmektedir. ${ }^{115} \mathrm{Bu}$ süreçte Knidos, Patara ve İskenderiye arasındaki üretim-ticaret

111 Misır tanrıları Serapis, Harpokrates ve İsis'in, Knidos'un Roma İmparatorluk Dönemi'ne ait baz1 kandil ve oinophoros grubu kapları üzerinde yer bulduğu görülmektedir; bk. Doksanaltı 2006: 196-197.

112 Bailey 1972/1973: 11; Mandel 1988: 95-106; Mandel 2000: 64-66; Doksanalt1 2006: 425; Pastutmaz 2009: 31-33.

113 Mandel 1988.

114 Baldoni 2003.

115 Hayes 1997: 74; Pastutmaz 2009: 38. 
ağının belirlenmesine yönelik olarak; oinophoros grubu içinde ilk üretilen form olarak tespit edilen pateraların Knidos'ta üretilip buradan deniz yoluyla ihraç edilmiş olabileceği akla en uygun varsayımlardan biri gibi görünmektedir. Bununla birlikte, Patara'da ele geçen kalıp parçasının (Kat. No. 10), pateraların madalyon bölümlerinin üretiminde kullanılmaya son derece uygun fiziksel yapısı ve üzerinde taşıdığ 1 ikonografinin pateraların kabartmalarında kullanılan konu yelpazesine uygunluğu, Patara'da oinophoros grubu pateraların üretilmiş olup olamayacağ 1 sorusunu akla getirmektedir. Ancak eldeki veriler kısitlıdır ve bu nedenle, bu soruya az sayıdaki sabit üzerinden varsayımsal öneriler getirilebilmektedir. Öncelikle, yukarıda da değindiğimiz gibi Patara'da ele geçen örneklerin bir bölümünün Knidos üretimi oinophoroslarla yakın stil benzerliği içinde olduğu açıktır. Ancak, üç yüzyılı aşan bir süre üretimi devam eden bu seramik grubunun, özellikle de pateraların, hem Knidos ithallerinin hem diğer üretimlerin, en azından MS 1. yüzyılın ortalarından itibaren pazarda yer bulduğunu unutmamız gerekir. Örneğin üretim merkezlerinden biri olan İasos'ta hem yerel üretim oinophorosların hem de Knidos üretimi oinophorosların eş zamanlı olarak kullanıldığ 1 tespit edilmiştir.116 Kalıpların dolaşımının bilinmemesi ve kil analizlerinin yapılmamış olması da bir engel olarak bu sorunun yanitlanmasındaki zorluklardan birini oluşturmaktadır. Göz önünde bulundurulması gereken bir diğer olgu ise Patara'da ele geçen kalıbın farklı tiplerde seramik grupları için kullanılmış olabileceği ihtimalidir. Tüm bu nedenlerle, Patara'da bir üretim olup olmadığını açık bir şekilde belirlememiz oldukça zordur. Anadolu'nun özellikle batı ve güney kıyıları başta olmak üzere, Khios ve Samos gibi Ege adalarına, Misır'da İskenderiye ve Kahire gibi merkezlere, Korfu, Brindisi ve Aquileia gibi Adriatik yerleşimlerine ve Karadeniz çevresindeki birçok merkeze ${ }^{117}$ yayılan bu tip kapların üretiminin, bugüne kadar belirlenenden daha fazla merkezde gerçekleştirilmiş olabileceği düşünülmektedir. Bu bağlamda, Patara oinophoros grubu ile kalıp üzerine yaptığımız gözlemlerin; Knidos, Pergamon ve İasos atölyelerinin yanı sıra, başta Patara olmak üzere Anadolu'da oinophoros grubu kaplar üreten daha fazla sayıda

116 Baldoni 2003: 14

117 Baldoni 2003: 68. üretim merkezinin olma olasılığını artırdığını söylememiz mümkün görünmektedir.

\section{Katalog}

Kat. No. 1 (Fig. 1)

Env. No.: Ptr'19.676

Bul. Yeri: Nero Hamam1 - 3,48-336 - K. No. 13

Ölçü: Y: 13,6 cm; AÇ: $5,5 \mathrm{~cm}$

Hamur Rengi: 2,5 YR 6/6 - Açık Kırımızı

Astar Rengi: 2,5 YR 5/8 - Kırmız1

Tarih: MS 2-3. yüzyıl

Kat. No. 2 (Fig. 2)

Env. No.: Ptr'12.155

Bul. Yeri: Nekropol Alanı - Kesit

Ölçü: Y: 1,1 cm; KÇ: 6,6 cm

Hamur Rengi: 10 YR 6/1 - Gri

Astar Rengi: 5 YR 5/4 - Kırmızıms1-kahverengi

Tarih: MS 1-2. yüzy1l

Kat. No. 3 (Fig. 3)

Env. No.: Ptr'11.62

Bul. Yeri: Meclis Kuzey Sur - B-14 - K. No. 218

Ölçü: Y: 1,4 cm; KÇ: 6 cm

Hamur Rengi: 7,5 YR 6/1 - Gri

Astar Rengi: 2,5 YR 6/6 - Açık Kırmızı

Tarih: MS 1-2. yüzy1l

Kat. No. 4 (Fig. 4)

Env. No.: Ptr'10.61 - Müze Env. No.: Ptr. 2010.22

Bul. Yeri: Su Yolu - Sondaj 21 - 11.34-10.96

Ölçü: Y: 3,6 cm; KÇ: 10,6 cm

Hamur Rengi: 2,5 YR 6/6 - Açık Kırmızı

Astar Rengi: 10 R 5/6 - Kırmızı

Tarih: MS erken 3. yüzyıl

Kat. No. 5 (Fig. 5)

Env. No.: Ptr'09.726

Bul. Yeri: Meclis Kuzey Sur - 5,53-4,89

Ölçü: Y: 1,5 cm; KÇ: $10 \mathrm{~cm}$

Hamur Rengi: 7,5 YR 5/1 - Gri

Astar Rengi: 2,5 YR 6/6 - Açık Kırmızı

Tarih: MS 1. yüzy1l

Kat. No. 6 (Fig. 6)

Env. No.: Ptr'10.143

Bul. Yeri: Liman Caddesi - Bat1 Portikus - -116

Ölçü: Y: 1,8 cm; KÇ: $10 \mathrm{~cm}$

Hamur Rengi: 2,5 YR 6/6 - Açık Kırmızı

Astar Rengi: 10 R 5/6 - Kırmız1

Tarih: MS 1-3. yüzyıl 


\section{Kat. No. 7 (Fig. 7)}

Env. No.: Ptr'11.318

Bul. Yeri: Tak Önü-Sekizgen Yap1-K. No. 1

Ölçü: Y: $1,5 \mathrm{~cm}$; KÇ: $10 \mathrm{~cm}$

Hamur Rengi: 5 YR 6/4 - Açık Kırmızı-kahverengi

Astar Rengi: 10 R 5/8 - Kırmızı

Tarih: MS 1-3. yüzyı1

\section{Kat. No. 8 (Fig. 8)}

Env. No.: Ptr'99.98

Bul. Yeri: Tepecik Nekropol

Ölçü: Y: 1,6 cm; KÇ: $10 \mathrm{~cm}$

Hamur Rengi: 2,5 YR 6/6 - Açı1k Kırmızı

Astar Rengi: 10 R 5/6 - Kırmızı

Tarih: MS 1-2. yüzyı1

\section{Kat. No. 9 (Fig. 9)}

Env. No.: Ptr'09.BN

Bul. Yeri: Meclis Kuzey Sur - 7,49

Ölçü: Y: $1,8 \mathrm{~cm}$; KÇ: $10 \mathrm{~cm}$

Hamur Rengi: 7,5 YR 6/4 - Açık Kahverengi

Astar Rengi: 2,5 YR 5/8 - Kırmız1

Tarih: MS erken 3. yüzy1l

Kat. No. 10 (Fig. 10)

Env. No.: Ptr'99.TN

Bul. Yeri: Tepecik Nekropol - TN2/TN3

Ölçü: Y: 1,7 cm; G: 6,6 cm

Hamur Rengi: 7,5 YR 5/1 - Gri

Astar Rengi: -

\section{Kaynakça}

\section{Antik Kaynaklar}

Diod. Sic.: (=Diodoros Siculus, Bibliotheke Historike) Diodorus of Sicily in Twelve Volumes (çev. C. H. Oldfather), London 1989.

Hdt.: (=Herodotos, Historiae), Herodotos, Herodot Tarihi (çev. M. Ökmen) İstanbul 2006.

Paus.: (= Pausanias, Periegesis tes Hellados), Pausanian Description of Greece (çev. W. H. Jones), London 1918-1935.

Plut. Ant.: (= Plutarkhos, Bioi Paralleloi), Plutarch's Lives. (çev. B. Perrin), London 1959.

Strab.: (=Strabon, Geographika: XII-XIII-XIV) Antik Anadolu Coğrafyası. (çev. A. Pekman), İstanbul 1993. (Arkeoloji ve Sanat Yayınları).

\section{Modern Kaynaklar}

Ager 2005: S. L. Ager, "Familiarity Breeds: Incest and the Ptolemaic Dynasty" JHS 120, 1-34.

Ager 2006: S. L. Ager, "The Power of Excess: Royal Incest and the Ptolemaic Dynasty" Anthropologica 48.2, 165-186.
AugÉ 1986: C. Augé, "Dionysos (In Peripheria Orientali)" LIMC III.1, 514-531.

Bailey 1972/1973: D. M. Bailey, "Cnidian Relief Ware Vases and Fragments in the British Museum 1, lagynoi and head-cups", ReiCretActa 14-15, 11-25.

BAiley 1988: D. M. Bailey, A Catalogue of the Lamps in the British Museum III. Roman Provincial Lamps, London.

BALdoni 2003: D. Baldoni, Vasi a matrice di età età imperiale a Iasos, Missione archeologica Italiana di Iasos III. Archaeologica 139, Rome.

Blake 1930: M. E. Blake, "The Pavements of the Roman Buildings of the Republic and Early Empire" MemAmA 8, 7-159.

BreCCIA 1909: E. Breccia, "Di alcuni frammenti di vasi con rappresentanze a rilievo" BArchAlex 11.2, 298-320.

Bruneau 1972: P. Bruneau, Les Mosaïques, Délos 29, Paris.

Bulard 1908: M. M. Bulard, "Peintures murales et mosaiques de Délos" MonPiot 14.1-2, 7-214.

Buora vd. 2016: M. Buora, M. Magnani, "Una patera cnidia con scena erotica", bk. G. Cuscito (Ed.), Instrumenta inscripta VI. Le iscrizioni con funzione didascalico-esplicativa, Antichità Altoadriatiche 83, 411-424.

Courby 1913: F. Courby, "Vases avec reliefs appliqués du Musée de Délos", BCH 37, 418-444.

Cristofani 1986: M. Cristofani, "Fufluns" LIMC III.1, 531-540.

Doksanalti 2000: E. M. Doksanalt1, "Die Keramikfunde aus den Arealen Z1 und Y1 der Dionysos-Stoa in Knidos", ReiCretActa 36, 75-82.

Doksanalti I 2006: E. M. Doksanaltı, Knidos Kap Krio Kazı Alanı (Selçuk Üniversitesi, Sosyal Bilimler Enstitüsü, Yayımlanmamış Doktora Tezi) Konya.

Dunbabin 1978: K. M. Dunbabin, The Mosaics of Roman North Africa: Studies in Iconography and Patronage. Oxford.

Dunbabin 1999: K. M. Dunbabin, Mosaics of the Greek and Roman World, Cambridge.

EgGers 1955: H. J. Eggers, "Zur absoluten Chronologie der Romischen Kaiserzeit im Freien Germanien", JbRGZM 2, 196-244.

ERdoĞAn vd. 2018: A. Erdoğan - S. Arıc1, "Tripolis'de Bulunmuş Çocuk Dionysos Heykeli”, OLBA 26, 285-304.

Erhat 1996, A. Erhat, Mitoloji Sözlüğü, İstanbul.

FARNELl 1909: L. R. Farnell, The Cults of the Greek States V, Oxford.

FAthy 2019: E. Fathy, "Cultic Allusions in the Heraklitos Mosaic”, POTESTAS 14, 5-31.

Fuchs 1959: W. Fuchs, "Die Vorbilder der neuattischen Reliefs", JDI suppl. 20, 108-118. 
GASPARRI 1986a: C. Gasparri, "Dionysos", LIMC III.1, 414-514.

GASPARRI 1986b: C. Gasparri, "Bacchus", LIMC III.1, 540-566.

GreEt 2015: B. J. R. Greet, The Roman Eagle. Symbol and its Evolution (University of Leeds, Yayımlanmamış Doktora Tezi) Leeds.

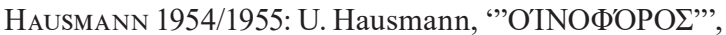
AM 69-70, 125-146.

Hayes 1997: J. W. Hayes, Handbook of Mediterranean Roman Pottery, London.

Hayes 1997: J. W. Hayes, Roman Pottery Fine Ware Imports, Athenian Agora 32, Princeton.

Heimberg 1976: U. Heimberg, "Oinophoren. Zur kaiserzeitlichen Reliefkeramik”, JdI 91, 251-290.

HiLgers 1969: W. Hilgers, Lateinische Gefäßnamen. Bezeichnungen, Funktion und Form römischer Gefäße nach den antiken Schriftquellen, RheinlandVerlag, Düsseldorf.

Işın 2007: G. Işın, Patara Terrakottaları. Hellenistik ve Erken Roma Dönemleri, Patara V.1, İstanbul.

İşKan (Ed.) 2019: H. İşkan (Ed.), Patara. Kent, Liman, Kült, İstanbul.

JÁcome 2013: P. M. Jácome, P. M., "Bacchus and Felines in Roman Iconography: Issues of Gender and Species", A. Bernabé (Ed.), Redefining Dionysos, Berlin, 526-540.

Jonas 1960: R. Jonas, "The Winged Dionysos", Internal circular 3, Israel Numismatic Society, Haifa Branch, 1960, 1-8.

KahiL 1992: L. Kahil, "Leda" LIMC VI.1, 231-246.

Lamb 1929: W. Lamb, Greek and Roman Bronzes, London.

LitvinskiJ vd. 1974: B. A. Litvinskij - N. O. Tursunov, "The Leninabad Krater and the Louvre Sosibios Vase (Neo-Attic Art and Central Asia)" East and West 24, 89-110.

Love 1969: I. C. Love, Knidos, bk. M. J. Mellink, Archaeology in Asia Minor, AJA 73.2, 216-219.

Mandel 1988: U. Mandel, Kleinasiatische Reliefkeramik der mittleren Kaiserzeit. Die "Oinophorengruppe" und Verwandtes, Pergamenische Forschungen 5, Berlin.

Mandel 2000: U. Mandel, "Die Frühe Produktion Der Sog. Oinophorenware- Werkstätten von Knidos", ReiCretActa 36, 57-68.

Masoud 2015: A. Masoud, "Lights on Sabazius Cult in Egypt Through An Unpublished Rare Hairpin" Egyptian Journal of Archaeological and Restoration Studies 5, 39-49.

Massa-Pairault vd. 1979: F. H. Massa-Pairault - J.-M. Pailler, Les terres cuites sous le péristyle, Bolsena $V$, La maison aux salles souterraines 1, Rome.
Matthews 1969: K. D. Matthews, Scutella, Patella, Patera, Patina: A Study of Roman Dinnerware, Philadelphia.

Ovadiah 2012: A. Ovadiah, "The Hellenistic Mosaic Head from Dor, Israel. Reconsidered', Gerión 30, 91-102.

PAILler 2000: J.-M. Pailler, "Mystères dissipés ou mystères dévoilés? À propos de quelques études récentes sur la fresque de la «Villa des Mystères » à Pompéi”, Topoi 10/1, 373-390.

PAPen 1905: F. G. von Papen, Der Thyrsos in der griechischen und römischen Literatur und Kunst, Berlin.

Pastutmaz 2009: D. Pastutmaz, Knidos Üretimi Kabartmalı Seramikler (Selçuk Üniversitesi, Sosyal Bilimler Enstitüsü, Yayımlanmamış Doktora Tezi) Konya.

Pastutmaz 2011: D. Pastutmaz, "Die Ikonographie des Dionysos auf knidischen Oinophoroi", Asia Minor Studien 66, 97-105.

PARrish 1981: D. Parrish, "The Mosaic Program of the Maison de la Procession Dionysiaque at El Jem", bk. Y. Duval (Ed.) Mosaique romaine tardive: l'iconographie du temps, les programmes iconographiques des maisons africaines, Paris, 51-64.

Pernice 1938: E. Pernice, Pavimente und figurliche Mosaiken, Berlin.

Pesando 1996: F. Pesando, "Autocelebrazione aristocratica e propaganda politica in ambiente privato: la casa del Fauno a Pompei", Cahiers $d u$ Centre Gustave Glotz 7, 189-228.

PiCARD 1935: C. Picard, "Dionysos Psilax," Melanges offerts a Octave Navarre, Toulouse, 317-337.

Pinckernelle 2007: K. Pinckernelle, The Iconography of Ancient Greek and Roman Jewellery (University of Glasgow, Yayımlanmamış Yüksek Lisan Tezi) Glasgow.

Pollitt 1986: J. J. Pollitt, Art in the Hellenistic Age, Cambridge.

Pons 1997: E. Pons, "Conjunto de terracotas egipcias de época greco-romana del Museo Arqueológico Nacional", Boletín del MAN 15, 95-119.

Rekowska 2013: M. Rekowska, "L’amour à Ptolémaïs... Scènes érotiques sur des objets découverts par les fouilles polonaises", bk. V. Dobrowski (Ed.), Et in Arcadia ego: studia memoriae professoris Thomae Mikocki dicata, Institute of Archaeology, Warsaw, 61-73.

RoBINSON 1909: D. M. Robinson, "An Oenophorus Belonging to the Johns Hopkins University", AJA 13, 30-38.

RoBERTSON 1965: M. Robertson, "Greek Mosaics” JHS 85, 72-89. 
SALOMONSON 1979: J. W. Salomonson, "Kleinasiatische Tonschalen mit Reliefverzierung", BABesch 54, 117-137.

SALOMONSON 1980: J. W. Salomonson, "Der Trunkenbold und die Trunkene Alte. Untersuchungen zur Herkunft, Bedeutung und Wanderung einiger plastischer Gefässtypen der römischen Kaiserzeit" BABesch 55, 65-135.

SCREECH 1980: M. A. Screech, "The Winged Bacchus (Pausanias, Rabelais and Later Emblematists)" JWCI 43, 259- 262.

SiCHTERMANN 1988: H. Sichtermann, "Ganymedes”, LIMC IV.1, 154-169.

Stone 2014: S. C. Stone, The Hellenistic and Roman Fine Pottery, Morgantina Studies 6, Princeton.

ŞAнin 2018: F. Şahin, Patara Metal Buluntularl, Patara V.2, İstanbul 2018.

Şaнin 2019: F. Şahin, A Patera of the Oinophoros Group and a Mold from Patara, Izmir Demokrasi Üniversitesi, II. Uluslararası Sosyal Bilimlerde Kritik Tartışmalar Kongresi, 2019, 1309-1318.

TiNH 1986: T. T. Tinh 1986, “Bes” LIMC III.1, 98-108.

ToDisco 1990: L. Todisco, "Herakles and the Cretan Bull (Labour VII)" LIMC V.1, 59-67.

Treister 2020: M. Y. Treister, "Римские Бронзовые Сосуды C Медальонами С Фигурными Изображениями Из Сарматии", A. Belousov - C. Ilyushechkina (Eds), HOMO OMNIVM HORARVM. Symbolae ad anniuersarium septuagesimum professoris Alexandri Podosinov dedicatae, Москва, 565-610.

Tulunay 2005: E. T. Tulunay, "Soloi Pompeiopolis Heykelleri (2000-2003)", AST 22.2, 23-30.

Weber 1892: G. Weber, "Bas-Reliefs de Laodicée et de Tripolis", $R A$ 20, 288-290.

Worrle 1977: M. Wörrle, "Epigraphische Forschungen zur Geschichte" Lykiens I, Chiron 7, 43-46.

Makale Gönderim Tarihi: 15.02.2021

Makale Kabul Tarihi: 26.03.2021

\section{FEYZULLAH ŞAHİN}

Orcid ID: 0000-0001-7110-8367

İzmir Demokrasi Üniversitesi Fen-Edebiyat Fakültesi, Arkeoloji Bölümü, İzmir/TÜRKIYYE

feyzullah.sahin@idu.edu.tr 


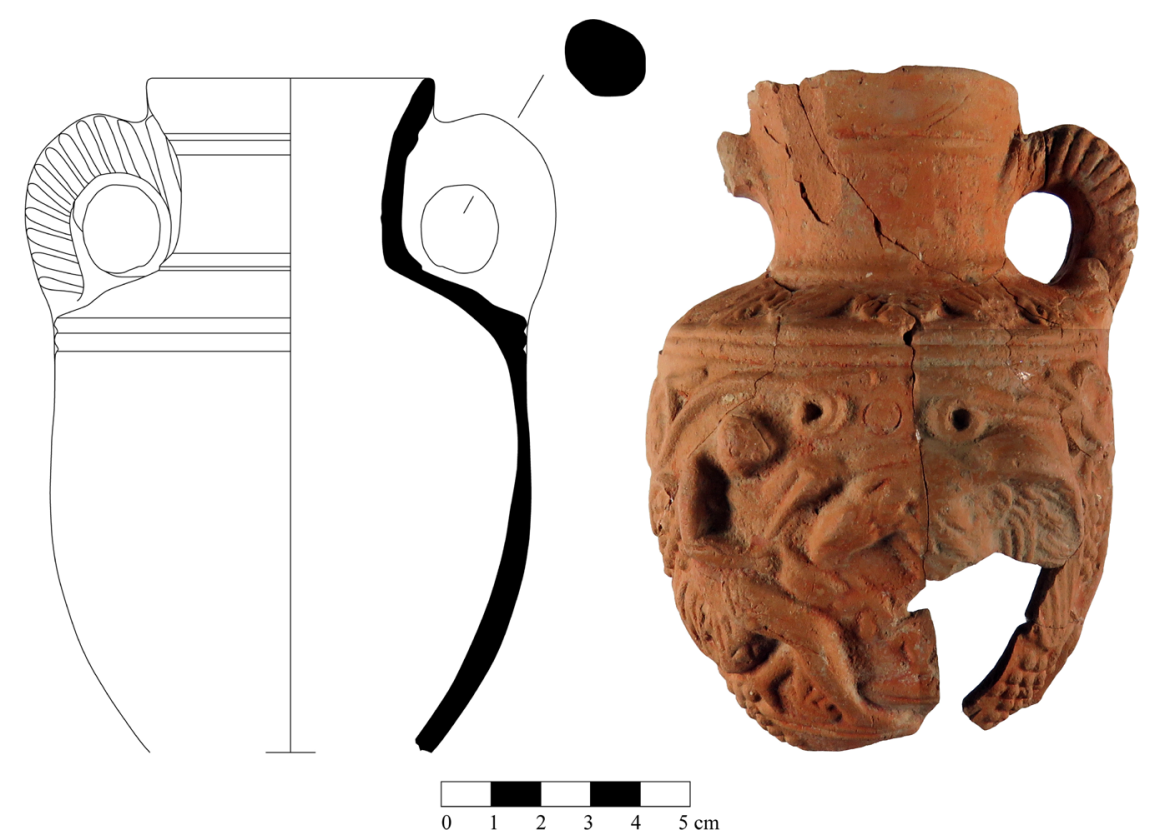

Fig. 1. Amphora - Kat. No. 1 (Patara Kazı Arşivi).
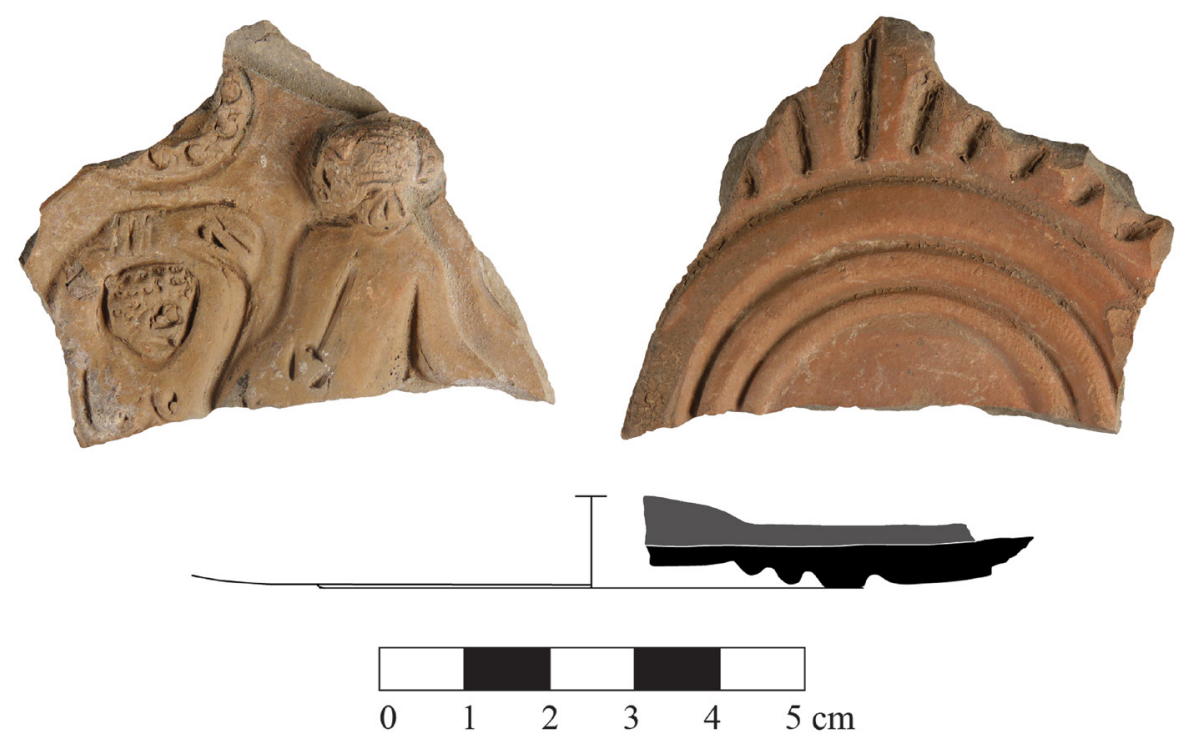

Fig. 2. Patera - Kat. No. 2 (Patara Kazı Arşivi). 

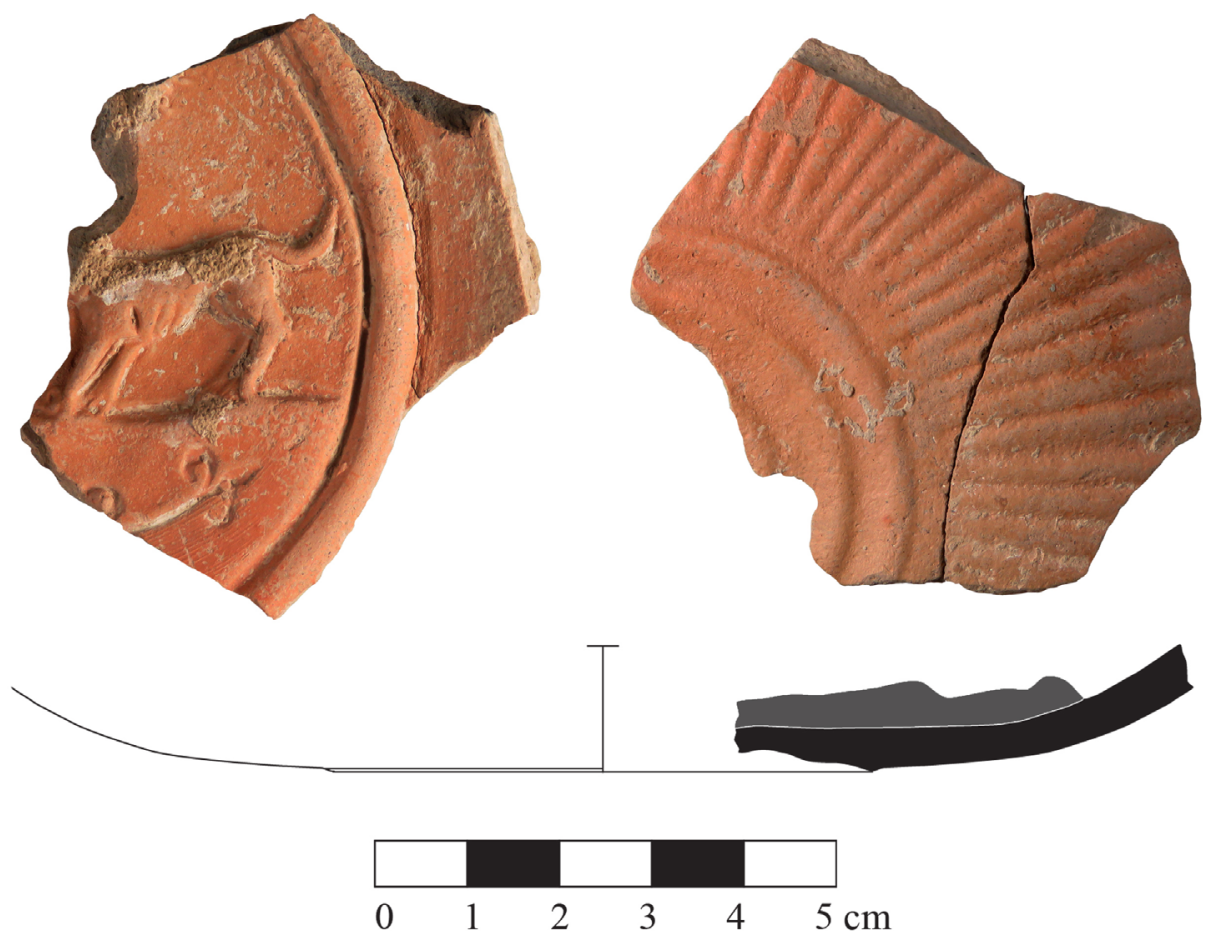

Fig. 3. Patera - Kat. No. 3 (Patara Kazı Arşivi).

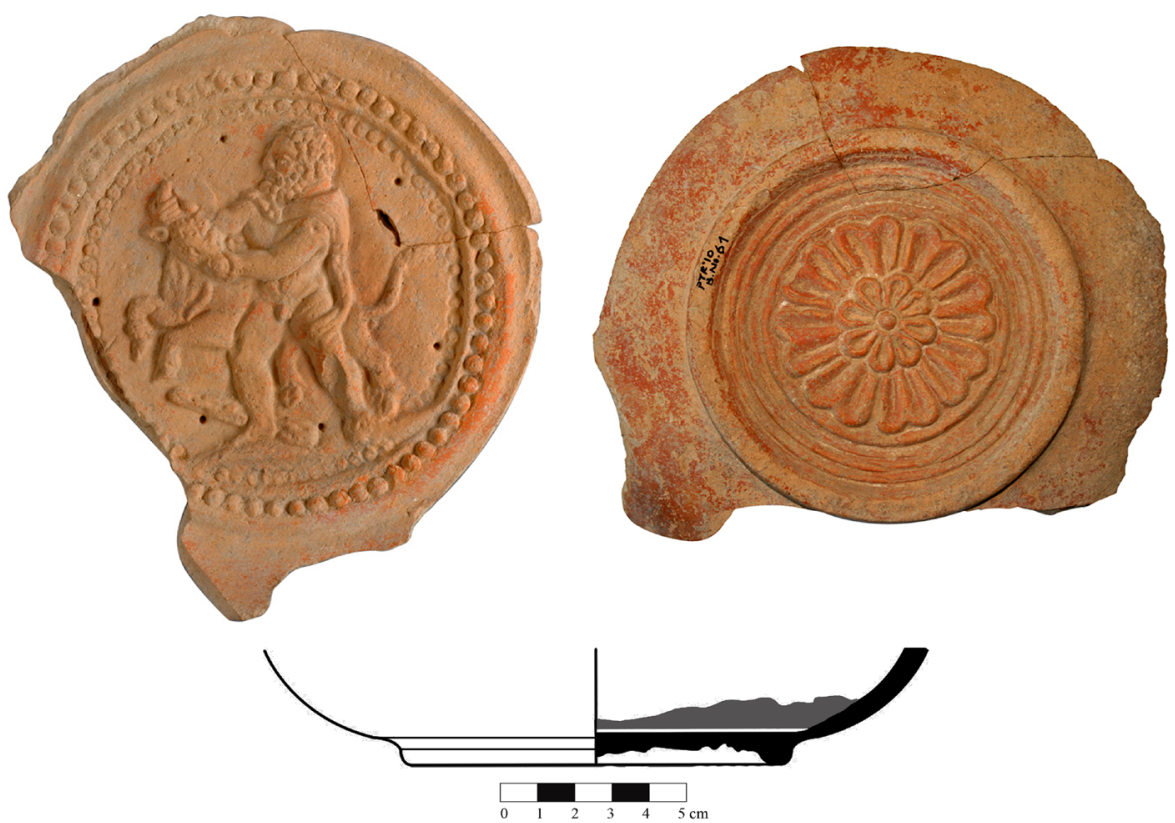

Fig. 4. Patera - Kat. No. 4 (Patara Kazı Arşivi). 


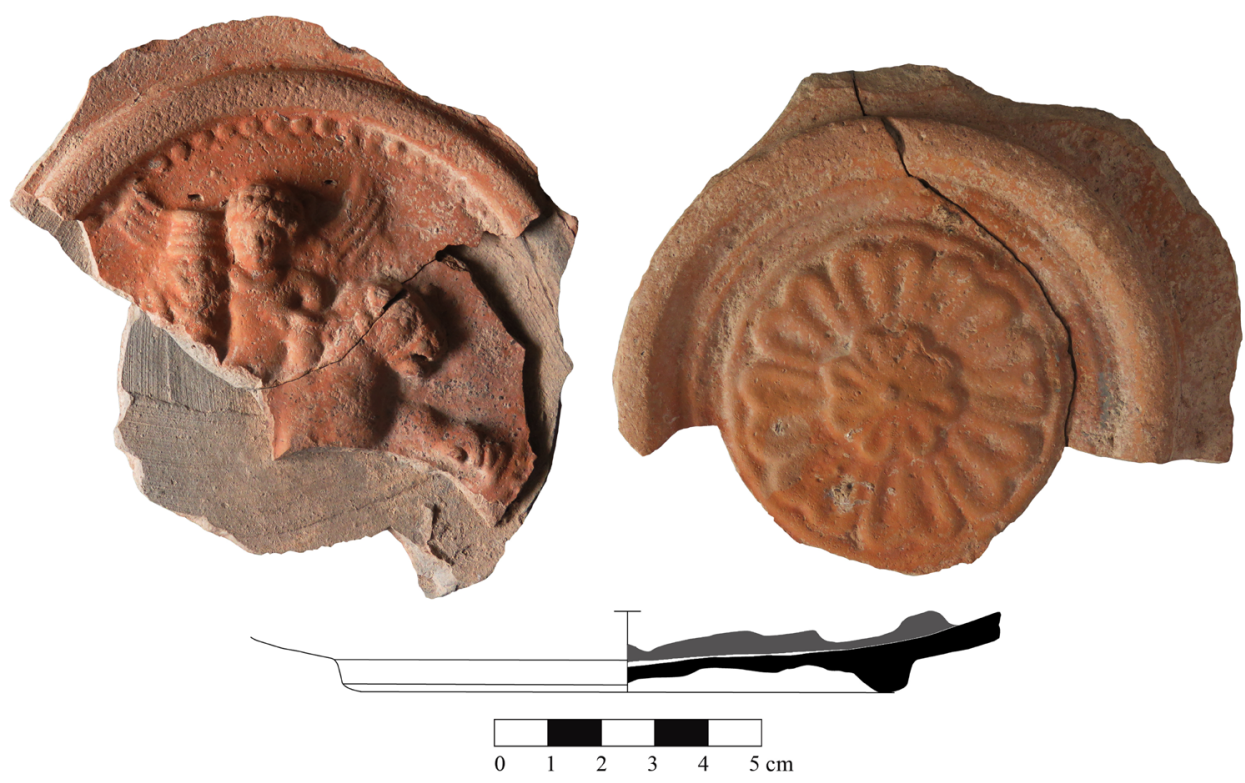

Fig. 5. Patera - Kat. No. 5 (Patara Kazı Arşivi).
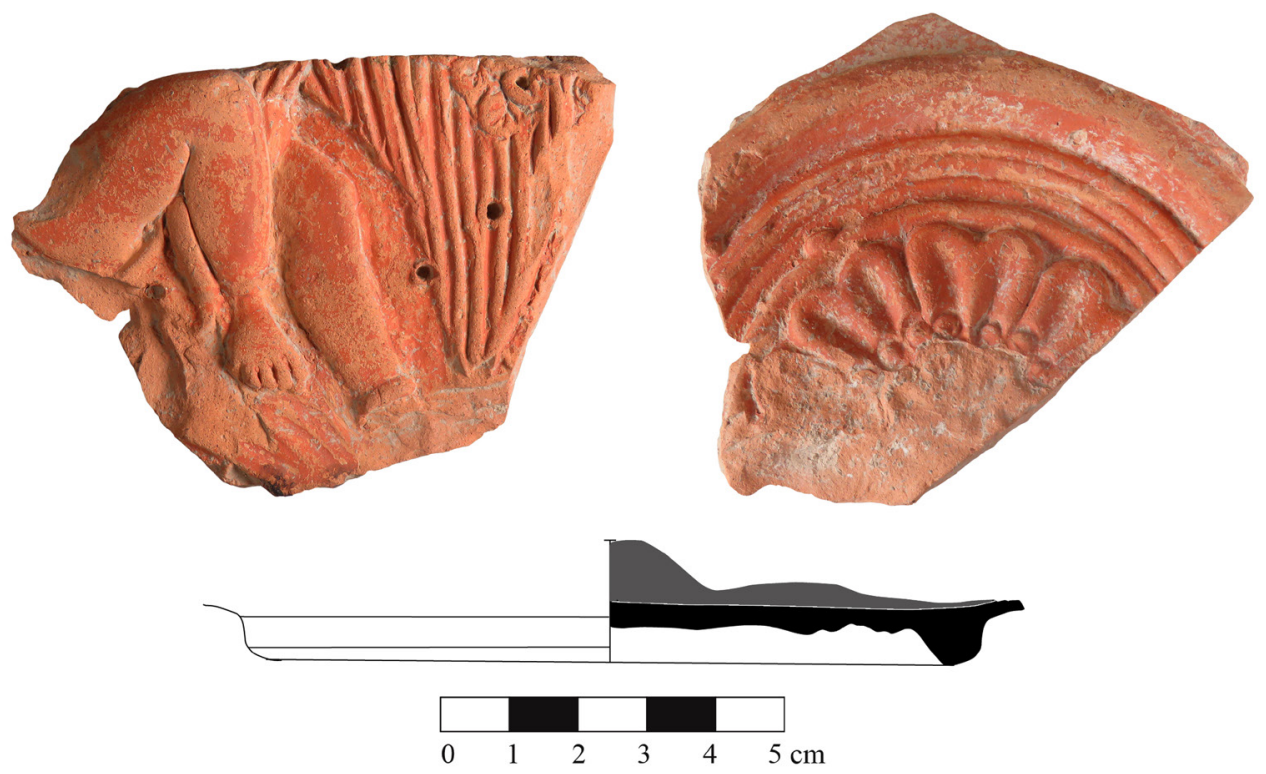

Fig. 6. Patera - Kat. No. 6 (Patara Kazı Arşivi). 


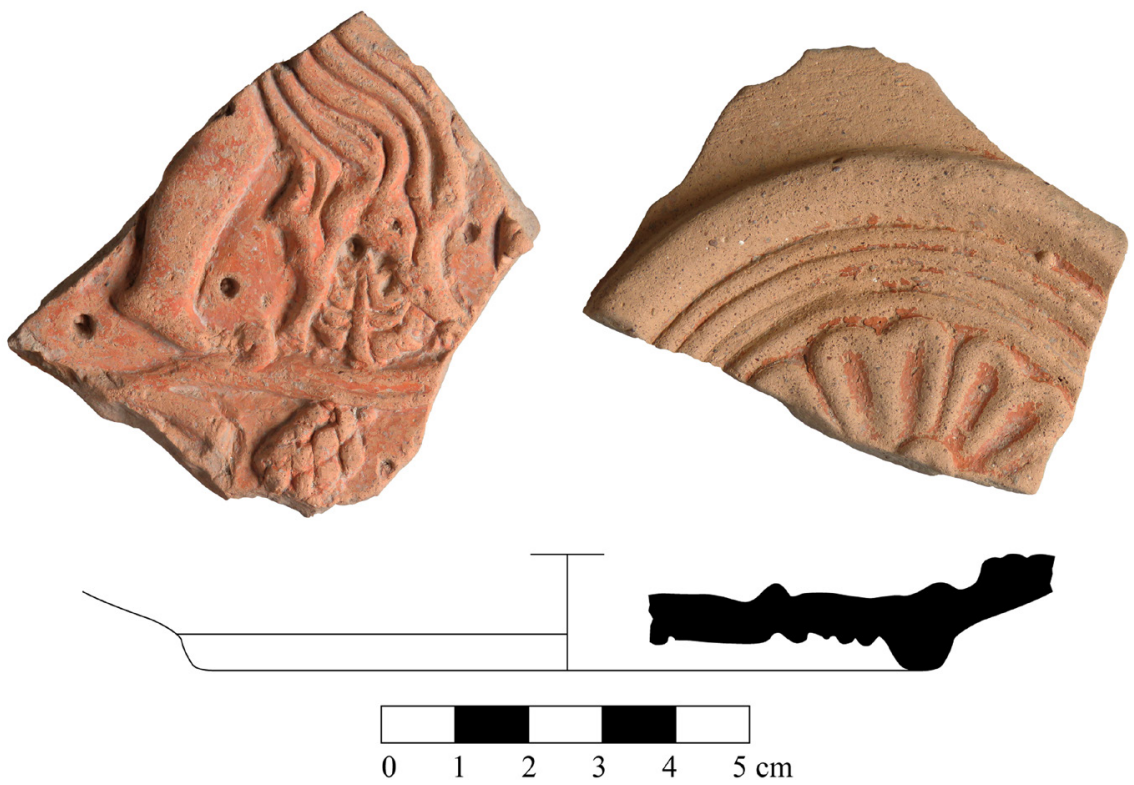

Fig. 7. Patera - Kat. No. 7 (Patara Kazı Arşivi).

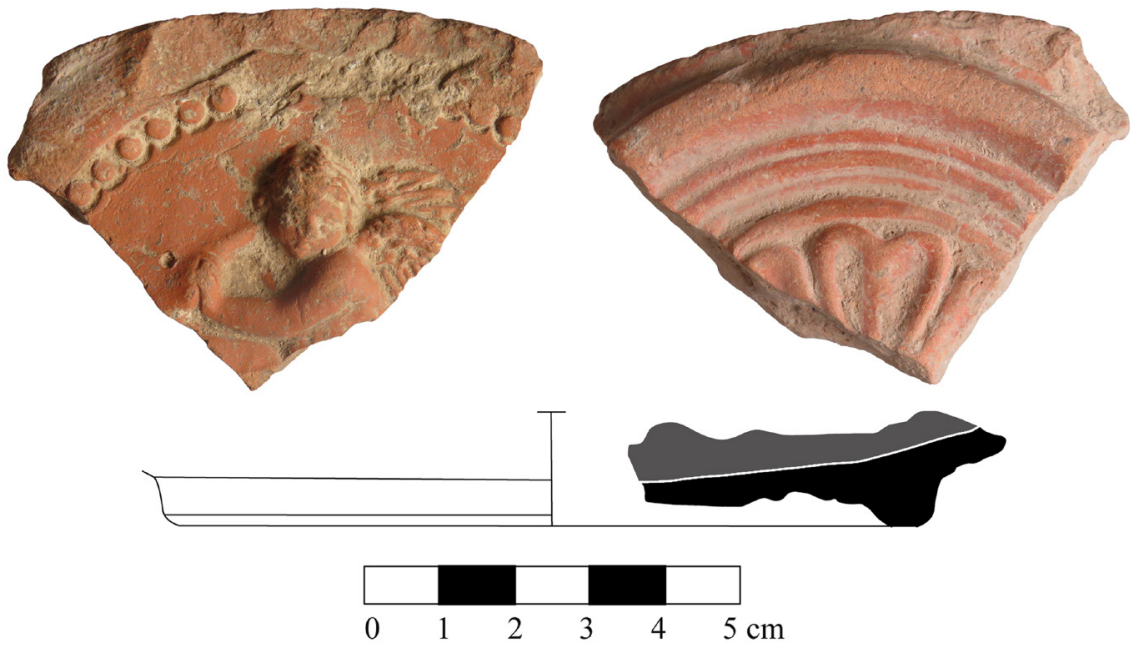

Fig. 8. Patera - Kat. No. 8 (Patara Kazı Arşivi). 


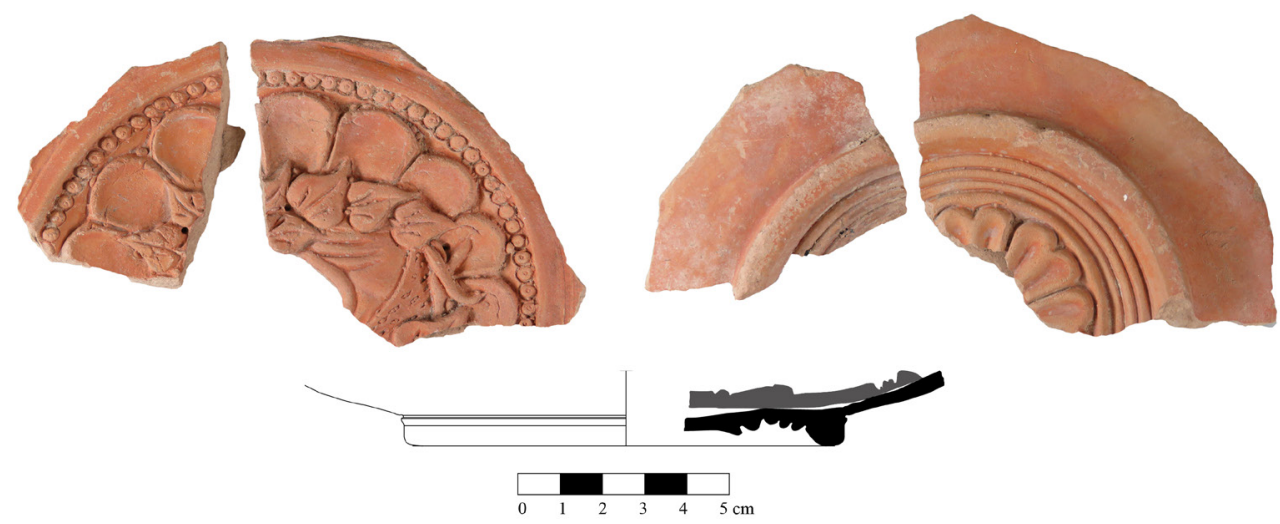

Fig. 9. Patera - Kat. No. 9 (Patara Kazı Arşivi).

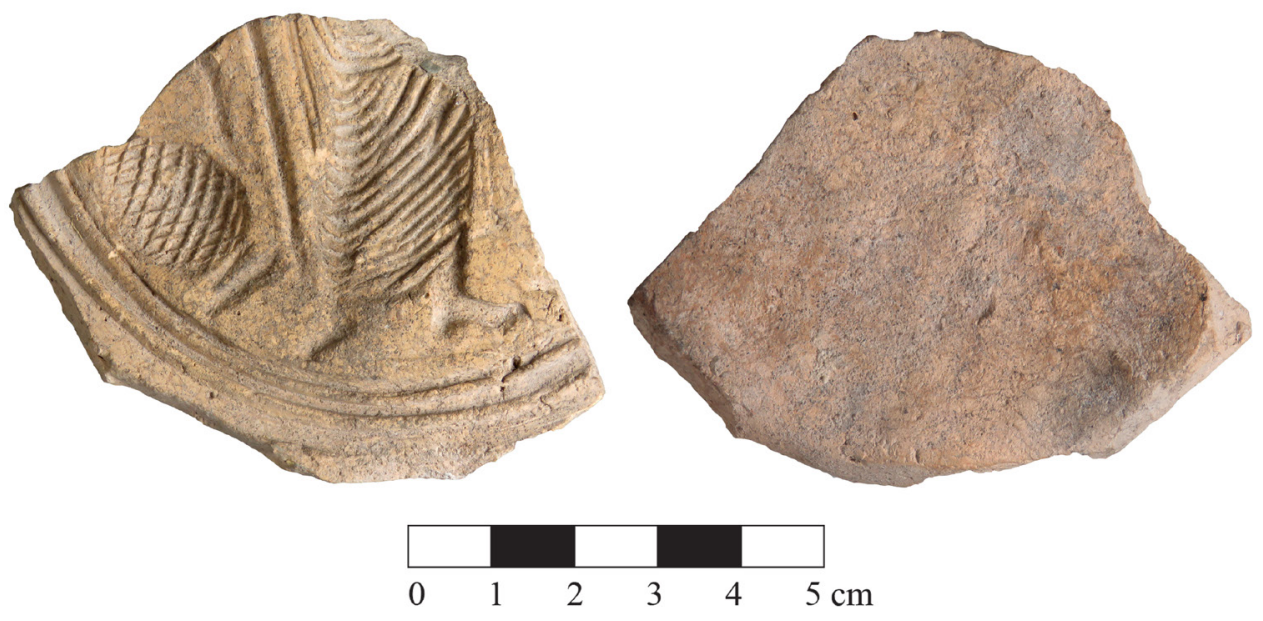

Fig. 10. Kalıp - Kat. No. 10 (Patara Kazı Arşivi).
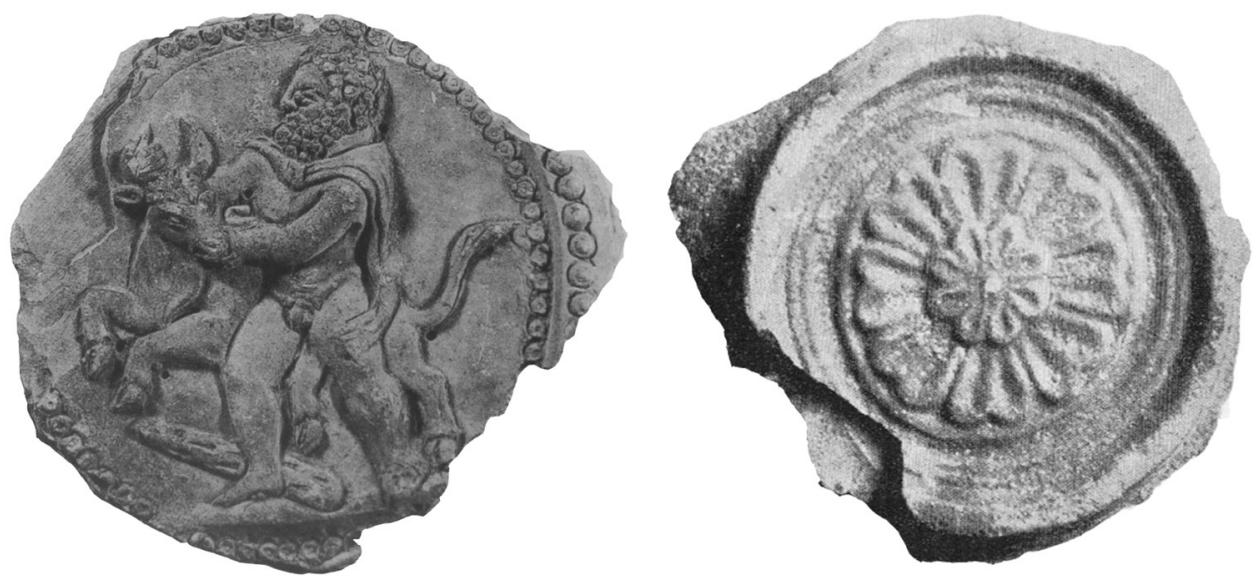

Fig. 11. Patera - İskenderiye Müzesi (Env. No. Alexandria.17001) - Breccia 1909: 364, Res. 61. 